Please do not remove this page

RMIT

UNIVERSITY

\title{
How do foreign institutional investors enhance firm innovation?
}

Luong, Hoang Luong; Moshirian, Fariborz; Nguyen, Lily; Tian, Xuan; Zhang, Bohui

https://researchrepository.rmit.edu.au/esploro/outputs/9921863120801341/filesAndLinks?institution=61RMIT_INST\&index=null

Luong, H. L., Moshirian, F., Nguyen, L., Tian, X., \& Zhang, B. (2017). How do foreign institutional investors enhance firm innovation? Journal of Financial and Quantitative Analysis, 52(4), 1449-1490.

https://doi.org/10.1017/S0022109017000497

Document Version: Accepted Manuscript

Published Version: https://doi.org/10.1017/S0022109017000497

Repository homepage: https://researchrepository.rmit.edu.au

(C) 2017 Michael G. Foster School of Business, University of Washington.

Downloaded On 2023/04/27 01:33:01 +1000 
Thank you for downloading this document from the RMIT Research Repository.

The RMIT Research Repository is an open access database showcasing the research outputs of RMIT University researchers.

RMIT Research Repository: http://researchbank.rmit.edu.au/

\author{
Citation: \\ Luong, H, Moshirian, F, Nguyen, L, Tian, X and Zhang, B 2017, 'How do foreign \\ institutional investors enhance firm innovation?', Journal of Financial and \\ Quantitative Analysis, vol. 52, no. 4, pp. 1449-1490.
}

See this record in the RMIT Research Repository at:

https://researchbank.rmit.edu.au/view/rmit:46537

Version: Accepted Manuscript

\title{
Copyright Statement:
}

(C) 2017 Michael G. Foster School of Business, University of Washington.

Link to Published Version:

https://dx.doi.org/10.1017/S0022109017000497 


\section{How Do Foreign Institutional Investors Enhance Firm Innovation?}

Hoang Luong, Fariborz Moshirian, Lily Nguyen, Xuan Tian, and Bohui Zhang*

Current Version: December, 2016

*Luong, hoang.luong@fulbrightmail.org, Moshirian, f.moshirian@unsw.edu.au, UNSW Business School, University of New South Wales; Nguyen, lily.nguyen@latrobe.edu.au, La Trobe Business School, La Trobe University; Tian (corresponding author), tianx@pbcsf.tsinghua.edu.cn, PBC School of Finance, Tsinghua University; and Zhang, bohui.zhang@unsw.edu.au, UNSW Business School, University of New South Wales, and Shenzhen Finance Institute, School of Management and Economics, The Chinese University of Hong Kong, Shenzhen. We thank Jarrad Harford (the editor) and Sara Holland (the referee) for their valuable comments and suggestions that have helped improve our paper significantly. We are grateful for constructive comments from Rachita Gullapalli, Marco Pagano, Terry Walter, and the participants at the 2015 Financial Management Association Annual Meeting, the 2014 Entrepreneurial Finance and Innovation Conference, and the 2013 Financial Integrity Research Network Research Topic Group Meeting in Corporate Finance. Tian acknowledges financial support from Tsinghua University Research Grant (Project No. 20151080451). All errors remain our own. 


\begin{abstract}
We examine the effect of foreign institutional investors on firm innovation. Using firm-level data across 26 non-U.S. economies between 2000 and 2010, we show that foreign institutional ownership has a positive, causal effect on firm innovation. We further explore three possible underlying mechanisms through which foreign institutions affect firm innovation: foreign institutions act as active monitors, provide insurance for firm managers against innovation failures, and promote knowledge spillovers from high-innovation economies. Our paper sheds new light on the real effects of foreign institutions on firm innovation.
\end{abstract}

JEL Classifications: G23; G32; G34

Keywords: Foreign Institutional Investors; Firm Innovation; Monitoring; Tolerance for Failure; Knowledge Spillovers 


\section{Introduction}

Technological innovation determines a country's long-term economic growth (Solow (1957)). Despite various efforts to promote innovation, it remains a significant challenge for firms in economies outside the United States to engage in innovative activities. ${ }^{1}$ Existing literature shows that firms' obstacles to innovation are often formed internally according to the country's culture and institutional environments (e.g., Acharya and Subramanian (2009), Brown, Martinsson, and Petersen (2013), Hsu et al. (2014), and Xie, Zhang, and Zhang (2016)). ${ }^{2}$ In this study, we propose an external solution to overcome local firms' innovation constraints: foreign institutional investors. We investigate how foreign institutional investors affect firm innovation in non-U.S. economies.

We hypothesize that foreign institutional investors are able to enhance firm innovation. This conjecture is motivated by Aghion, Van Reenen, and Zingales's (2013) findings that institutional investors promote innovation in U.S. firms. Foreign institutional investors not only share common characteristics of financial institutions, but also possess unique features that are different from domestic institutional investors. Specifically, foreign institutions are credited with their independence from local management, with holding internationally diversified portfolios, and with expertise in monitoring firms (e.g., Gillan and Starks (2003), Grinblatt and Keloharju (2000)). According to FactSet, foreign institutional ownership accounts for about $50 \%$ of total

\footnotetext{
${ }^{1}$ See Hsu, Tian, and Xu (2014) and Chang, McLean, Zhang, and Zhang (2015) for a stylized distribution of innovation output around the world.

${ }^{2}$ According to Carayannis, Samara, and Bakouros ((2015), p. 73), "in only a few cases the basic barriers are the scientific or technological problems. Usually, organizational, administrative, and institutional problems get in the way." Chen, Leung, and Evans (2016) find that a firm's treatment of its employees affects innovation.
} 
institutional ownership in non-U.S. firms, which is substantially different from that in the United States. ${ }^{3}$ As an important force in non-U.S. economies, we expect that foreign institutions promote firms' innovation activities and strategies for at least three reasons. ${ }^{4}$

First, when the market cannot observe the full spectrum of managerial actions, moral hazard could induce managers to shirk and avoid investment in risky and costly innovative projects (Hart (1983), Bertrand and Mullainathan (2003)). Even worse, managers could divert firms' resources for their own private benefit and retain less capital for investment in innovative projects. Throughout this corporate capital-allocation process, institutional investors can act as corporate monitors and actively intervene to create firm value (e.g., Shleifer and Vishny (1986), Kahn and Winton (1998), Burkart, Gromb, and Panunzi (1997), and Gillan and Starks (2003)). Specifically, Gillan and Starks (2003) argue that, due to their independent positions and a lack of conflicts of interest, foreign institutional investors play a more important role in corporate

\footnotetext{
${ }^{3}$ The ownership structure of U.S. firms is different from that of non-U.S. firms in the sense that foreign institutional ownership of U.S. firms accounts for just a negligible proportion of total equity ownership. For example, according to FactSet, foreign institutional investors hold merely $1.8 \%$ while domestic institutions own as much as $38.4 \%$ for an average U.S. firm during the $2000-2010$ period. To the best of our knowledge, the impact of institutional investors outside the United States, especially that of foreign institutions, on firm innovation is still largely unanswered in the literature.

${ }^{4}$ A famous recent anecdote supports the innovation-enhancing role of foreign institutional investors. Alibaba, a Chinese e-commerce company, raised \$25 billion in Sept. 19, 2014, which is the world's largest initial public offering (IPO). Alibaba is regarded as one of the most innovative companies in China. Before Alibaba's IPO, it was financed by SoftBank (a Japanese investment company) and Yahoo (a U.S. technology firm) who later became Alibaba's largest and second largest shareholder, respectively. Due to Alibaba's IPO success in the United States, a question is frequently raised by the Chinese public and regulators: why are innovative Chinese firms typically financed by foreign institutions?
} 
governance than domestic peers. This statement is further supported by Aggarwal, Erel, Ferreira, and Matos's (2011) finding that foreign institutional investors are proactively involved in monitoring investee firms worldwide. Therefore, we expect that intensive monitoring by foreign institutions can induce managers to invest in long-term, value-enhancing innovative activities. We call this view the monitoring channel.

Second, optimal incentive contracts that motivate innovation should exhibit substantial tolerance for early failure and reward for long-term success (e.g., Manso (2011), Ederer and Manso (2013)). Aghion et al. (2013) state that if incentive contracts cannot fully motivate innovation, institutional investors could step in to alleviate managers' career or reputational concerns by providing them with insurance against early failures of their innovative activities. Compared with domestic peers, foreign institutional investors hold internationally diversified portfolios, and thus should have a greater ability to tolerate the failure risk of investing in innovative projects. Therefore, they are more likely to insulate managers from punishment for innovation failures. We expect that the tolerance for failure by foreign institutions would encourage firm innovation. We term this view the insurance channel.

Third, investments in knowledge creation by one party create positive externalities in innovation on the other parties (Jaffe, Trajtenberg, and Fogarty (2000)). ${ }^{5}$ Foreign institutions could facilitate knowledge spillovers through business networks. ${ }^{6}$ For example, anecdotal

\footnotetext{
${ }^{5}$ There are a number of factors that affect knowledge spillovers, such as the mobility of highly skilled human capital (Agrawal, Cockburn, and McHale (2006)), international trade and foreign direct investment (Branstetter (2006)), and geographic location (Keller (2002)).

${ }^{6}$ Networks create value by synthesizing information and knowledge, exploiting expertise and pooling resources across traditional boundaries to create new knowledge and achieve innovations outside of individual
} 
evidence shows that foreign institutions can act as a bridge for networks of managers, investors, and other stakeholders of foreign and domestic firms to exchange opportunities and knowledge. ${ }^{7}$ Moreover, given that foreign institutional investors promote cross-border mergers and acquisitions (Ferreira, Massa, and Matos (2010)), these cross-border investments could facilitate knowledge spillovers and further contribute to local firms' innovation activities (e.g., Guadalupe, Kuzmina, and Thomas (2012)). Taken together, foreign institutions could enhance knowledge spillovers across countries through promoting business networks and cross-border mergers and acquisitions, which could contribute to the success of innovation activities in investee firms. We call this view the knowledge spillover channel.

We test our hypothesis using data from 26 non-U.S. economies for the 2000-2010 period. The data are from a unique international database of firm-level patents and citations, the Derwent World Patents Index (DWPI) compiled by Thomson Reuters. The existing cross-country studies on innovation typically use either research and development (R\&D) expenditures from the Worldscope database or the number of patents granted by the United States Patent and Trademark Office (USPTO) as innovation measures. These measures, however, have some limitations. ${ }^{8}$ Our innovation measures based on patents granted by both domestic and foreign

capabilities and resource bases of individual organizations (Johnson, Heimann, and O’Neill (2001), Pawar and Sharifi (2000), Prasad and Akhilesh (2002), Ratcheva and Vyakarnam (2001), and Trott (2008)).

${ }^{7}$ For example, the chief executive officer (CEO) of BlackRock, a leading U.S. investment management company with investments in over 100 countries and offices in 30 countries including India, offered to host a global investors meeting in India in early 2015.

${ }^{8}$ We discuss the limitations of existing innovation measures used in cross-country studies in greater detail in Section II. 
patent offices are complementary to the use of R\&D investments in measuring innovative activities.

Our baseline results show a positive relation between foreign institutional ownership and firm innovation output, consistent with our hypothesis. Specifically, an increase in foreign institutional ownership from the 25 th percentile to the 75 th percentile is associated with a $5.6 \%$ increase in patent counts and a 7.8\% increase in patent citations in the following year. This result is economically significant.

Although the above evidence supports our hypothesis, an important concern is that the relation between foreign institutions and firm innovation could be endogenously determined. Specifically, the result could be biased by unobservable firm and country characteristics that are correlated with both foreign institutional ownership and firm innovation (i.e., the omitted variable concern), or by the possibility that firms with greater innovation potential attract more foreign institutional investors (i.e., the reverse causality concern). As a result, a positive association between foreign institutional ownership and firm innovation does not necessarily imply that foreign institutions increase firm innovation. To address these endogeneity concerns, we use 2 different identification strategies.

Our first identification strategy is to use a difference-in-differences (DID) approach that relies on plausibly exogenous variation in foreign institutional ownership generated by a quasinatural experiment: the passage of the U.S. Jobs and Growth Tax Relief Reconciliation Act (JGTRRA) of 2003. The JGTRRA was designed to lower dividend tax rates not only for U.S. firms but also for firms domiciled in foreign countries that have tax treaties with the United States. Dividend-paying stocks in treaty countries thus become more attractive to U.S. institutional investors after the passage of the JGTRRA. If U.S. institutions tilt their portfolio 
allocations to dividend-paying stocks in treaty countries following the passage of the JGTRRA, the event would create plausibly exogenous variation in U.S. foreign institutional ownership in non-U.S. firms. After undertaking a number of diagnostic tests to ensure the satisfaction of the parallel trend assumption, the key identifying assumption of the DID approach, we find that firms with an increase in U.S. foreign institutional ownership generate a larger number of patents and citations than those that do not experience an increase in U.S. foreign institutional ownership surrounding the enactment of the JGTRRA.

Our second identification strategy is based on an instrumental variable (IV) approach. We follow Aggarwal et al. (2011) and use the time-varying membership of the Morgan Stanley Capital International (MSCI) All Country World Index between 2000 and 2010 as an instrumental variable for foreign institutional ownership. According to MSCI Inc., the MSCI is the industry's accepted gauge of global stock market activity and is a commonly used benchmark index for foreign institutional investors. Ferreira and Matos (2008) and Leuz, Lins, and Warnock (2010) find that the MSCI membership increases a firm's probability of attracting foreign capital. More importantly, it is reasonable to believe that the inclusion of the MSCI membership is less likely to depend on a firm's innovation output. Our IV approach analysis continues to find a positive effect of foreign institutional ownership on firm innovation.

We next examine three plausible underlying economic mechanisms through which foreign institutions enhance firm innovation. First, to test the monitoring channel, we classify foreign institutional investors into independent and grey investors, as well as long-term and short-term investors. Compared with grey (or short-term) foreign institutions, independent (or long-term) foreign institutions are regarded as active monitors, who play a more important role in governing firms (e.g., Chen, Harford, and Li (2007)). Consistent with our conjecture, we find 
that only independent (or long-term) foreign institutions enhance firm innovation, while grey (or short-term) foreign institutions do not. Our evidence suggests that foreign institutional investors promote innovation through their active monitoring of firms.

Second, we explore the insurance channel. We find that the sensitivity of CEO turnover (or compensation) to performance is lower in firms with greater foreign institutional ownership. According to Manso (2011), a high sensitivity of CEO turnover (or compensation) to performance is detrimental to motivating firm innovation because these incentive contracts are intolerant of failure. Thus, this finding suggests that by providing insurance (against failure risk) to managers with career and reputational concerns, foreign institutional investors allow managers to focus more on long-term, risky investment in innovative projects and hence positively contribute to their investee firms' innovation output.

Finally, we examine the knowledge spillover channel. To the extent that foreign institutions could act as a bridge that facilitates knowledge spillovers from their home countries to investee countries, we expect foreign institutions from more innovative countries to play a greater role in promoting investee firms' innovation than those from less innovative countries. Consistent with our hypothesis, we find that the positive effect of foreign institutional ownership on firm innovation is largely driven by institutions from foreign countries with a high innovation level.

Our paper contributes to two strands of the literature. First, our paper is related to the literature on the economic impacts of foreign institutions. Existing evidence shows that foreign institutional ownership affects firm value and performance (Ferreira and Matos (2008)), promotes improvements in governance (Aggarwal et al. (2011)), and facilitates the global convergence of financial reporting practices (Fang, Maffett, and Zhang (2015)). In addition, 
foreign ownership, in the aftermath of financial liberalization, affects the cost of capital (Bekaert and Harvey (2000), Lau, Ng, and Zhang (2010)), real wages (Chari, Henry, and Sasson (2012)), consumption growth volatility (Bekaert, Harvey, and Lundblad (2006)), emerging equity market volatility (Bekaert and Harvey (1997)), and stock market liquidity (Ng, Wu, Yu, and Zhang (2016)). Our study documents the positive role of foreign institutional ownership in promoting technological innovation. Our evidence is consistent with the findings of a contemporaneous paper, Bena, Ferreira, Matos, and Pires (2017). Using a set of metrics such as tangible assets, intangible assets, human capital, and innovation output, they show that foreign institutional ownership fosters long-term investment. Our paper differs from theirs by providing extensive evidence on firm innovation and by exploring possible underlying economic mechanisms through which foreign institutional investors enhance innovation.

Second, our paper contributes to the emerging literature on finance and innovation by investigating an important driver of innovation outside the United States. There is a fast growing body of literature that examines, both theoretically and empirically, various ways to promote innovation. Manso (2011) shows that managerial contracts that tolerate failure in the short run and reward success in the long run are best at motivating innovation. Empirical evidence shows that laws (Acharya and Subramanian (2009), Acharya, Baghai, and Subramanian (2014)), financial market development (Hsu et al. (2014)), firm boundaries (Seru (2014)), stock liquidity (Fang, Tian, and Tice (2014)), market conditions (Nanda and Rhodes-Kropf (2013)), financial analysts (He and Tian (2013)), banking competition (Cornaggia, Mao, Tian, and Wolfe (2015)), labor unions (Bradley, Kim, and Tian (2017)), product market competition (Aghion, Bloom, Blundell, Griffith, and Howitt (2005)), and corporate venture capital investors (Chemmanur, Loutskina, and Tian (2014)) all alter agents' incentives and affect innovation. However, there is 
little insight into the causal effect of foreign institutional investors. We fill in this gap by showing that foreign institutional investors are an important driver of firm innovation, particularly in less innovative economies.

Our study complements the work of Aghion et al. (2013). In their model, institutional investors are assumed to affect stock prices through either the threat of exit or voice. Using a sample of U.S. firms, Aghion et al. (2013) show that institutional investors enhance firm innovation, which is consistent with the predictions of their model. Because the key assumptions of Aghion et al.'s (2013) model apply to an international setting, we expect institutional investors to have the same positive effect on firm innovation in non-U.S. countries.

Moreover, existing literature shows that, compared with domestic institutions, foreign institutions are more likely to use their threat of exit and voice as disciplinary mechanisms. For example, Ahmadjian and Robbins (2005) find that foreign institutional investors in Japan use both exit and voice to send clear messages to management about their interests. In more general studies, Gillan and Starks (2003) argue that, due to their independent positions and a lack of conflicts of interest, foreign institutions play a crucial role in promoting governance changes in local firms. Aggarwal et al. (2011) find that foreign institutional investors engage in monitoring investee firms worldwide, which results in higher operating performance and firm value.

Thus, in the spirit of Aghion et al. (2013), we argue that, through the monitoring channel as well as the insurance channel, foreign institutional investors would contribute positively to firm innovation. Our study also explores a new underlying channel, unique to foreign institutions, which facilitates knowledge spillovers from more to less innovative countries. Taken together, our study complements the work of Aghion et al. (2013) by documenting the positive effect of foreign institutional ownership on firm innovation. 
The paper proceeds as follows: Section II describes the data and the variable

construction. Section III presents our baseline results. Section IV addresses identification issues. Section V explores plausible underlying mechanisms. Section VI concludes.

\section{Data, Variable Construction, and Descriptive Statistics}

\section{A. Data}

Our sample includes publicly listed firms from 26 economies (excluding the United States) for the 2000-2010 period. We construct firm-level patent and citation variables based on the DWPI database compiled by Thomson Reuters. The DWPI is a comprehensive collection of global patent information in English, translated from over 30 languages. For example, in 2013, the DWPI contains patent data from 48 patenting authorities, covering 51 million patent documents and 23 million patent families across all innovation technologies.

We obtain institutional ownership data from the FactSet database, a leading source of global institutional ownership information. For non-U.S. firms, FactSet collects ownership data directly from sources such as national regulatory agencies, stock exchange announcements (e.g., the Regulatory News Service in the United Kingdom), local and offshore mutual funds, mutual fund industry directories (e.g., European Fund Industry Directory), and company proxies and financial reports. Because the FactSet historical ownership data are available from 1999 only, our sample period starts from 2000 and ends in 2010. We obtain firm accounting data from the Worldscope database.

To combine innovation, ownership, and accounting information from various databases, we match the DWPI's standardized assignee names with the names of public firms in Worldscope. We follow this procedure because the DWPI only provides firm names, and not stock identifiers. Following procedures specified on the National Bureau of Economic Research 
(NBER) patent database's website, we start with all DWPI patents, as well as the universe of firms from Worldscope that have firm names and non-missing SEDOL codes (SEDOL, which stands for Stock Exchange Daily Official List, is a 7-digit security identifier assigned by the London Stock Exchange). ${ }^{9}$ We use both exact and fuzzy matching methods to match the DWPI's assignee names with those from Worldscope. To eliminate any lingering doubt in the datamatching process, we manually search for information about sample firms from different newswire services and Internet sources. In this process, we require a firm to have valid innovation and accounting information to be included in the sample. Finally, we require an economy to have at least 10 firms to be retained in the sample. Our final sample covers 4,249 unique non-U.S. firms from 26 economies (with a total of 30,008 firm-year observations), of which 1,506 firms are located in emerging economies and 2,743 firms in developed economies.

\section{B. Variable Construction}

\section{Firm-Level Innovation Variables}

Due to the lack of global patent data, prior studies either construct innovation measures based on R\&D expenditures from Worldscope or use patents applied for through the USPTO as a proxy for a firm's total innovation output (e.g., Hsu et al. (2014)). According to the National Research Council, although R\&D expenditures are an important input of innovation process, they cannot adequately substitute for the innovation output (https://www.nap.edu/read/18606/chapter/6). First, many firms do not report R\&D expenditures in their financial statements due to differences in accounting standards among countries.

\footnotetext{
${ }^{9}$ For detailed information about the NBER patent and citation data cleaning and matching procedures, see https://sites.google.com/site/patentdataproject/Home/posts/namestandardizationroutinesuploaded.
} 
However, missing R\&D information does not necessarily mean that firms are not involved in innovative activities (Koh and Reeb (2015)).

Second, not all R\&D investments lead to patent granting because only successful or significant innovation is patentable. According to the World Intellectual Property Organization (WIPO), "the invention must consist of patentable subject matter, the invention must be industrially applicable (useful), it must be new (novel), it must exhibit a sufficient "inventive step" (be nonobvious), and the disclosure of the invention in the patent application must meet certain standards" (http://www.wipo.int/export/sites/www/about-ip/en/iprm/pdf/ch2.pdf). Our use of patents, a measure of innovation output or successful patent applications, captures an important dimension of innovation and thus is complementary to the use of R\&D investments in measuring innovative activities.

Third, many non-U.S. firms may not apply for patents to the USPTO, which results in an underestimation of innovation output using only U.S. patents as a proxy for non-U.S. firms' total innovation output. ${ }^{10}$ Comparing the USPTO with the DWPI, we find that the latter compiles more patents than the former, especially for innovative economies. For example, in Japan, there are a total of $212,034(285,283)$ patents filed by Japanese firms in the USPTO (DWPI), which

\footnotetext{
${ }^{10}$ There are two plausible reasons why many non-U.S. firms do not apply for patents through the USPTO.
} First, these non-U.S. firms may not do business in the United States. According to the U.S. patent law, patents filed to the USPTO are protected in the United States but not in other countries. As a result, firms that do not do business in the United States and hence do not need their intellectual property to be protected in the United States do not apply for patents through the USPTO. Second, "home-bias" in patenting due to patent policy familiarity and geographical distance could be another reason. Chang et al. (2015) find that about $39.1 \%$ of the patents owned by firms are awarded within a firm's home country and $76.3 \%$ of non-U.S. patents are filed in patent offices outside the United States. 
suggests that about $25 \%$ of Japanese patents in the DWPI are not covered in the USPTO.

Regarding Germany, there are a total of $29,484(35,528)$ patents from the USPTO (DWPI), which suggests that about $17 \%$ of awarded patents of German firms covered in the DWPI are not from the USPTO. We observe similar patterns in other economies such as Korea and Taiwan. ${ }^{11}$ The DWPI database contains information on all patents applied for through patent offices around the world. Therefore, we are able to construct more accurate measures for non-U.S. firm innovation using this database. From the DWPI database we obtain information on patent assignee names, application numbers, application dates, application countries, the number of future citations received by each patent, patent grant dates, and grant countries.

We construct 2 measures to capture firm innovation. The first one is a firm's total number of patent applications that are eventually granted in a given year; this measure captures a firm's innovation quantity. We use a patent's application year instead of its grant year because the former is superior when capturing the actual time of innovation (Griliches, Pakes, and Hall (1988)). To account for the fact that a patent can be assigned to multiple assignees in the DWPI database, we scale a patent by the number of assignees that own the patent, assuming equal patent ownership. Because a patent may belong to more than one technology group, we further scale this measure by the mean number of patent applications filed in a year for technology groups to which the patent belongs. The DWPI database classifies all patents into 3 broad categories (chemical, engineering, and electronic and electrical engineering), which are further divided into 20 broad subject areas (see Appendix A for details). We use these 20 patent groups to normalize our first innovation measure.

\footnotetext{
${ }^{11}$ Of course, for studies focusing on U.S. firms, the USPTO database has its own comparative advantage because its patenting policy and patent application and granting procedures are all standardized.
} 
The second measure is the total number of citations received by each patent in subsequent years, scaled by the average citation count received by each patent for the technology group of patents to which the patent of interest belongs. This measure is better for assessing the quality of a patent because it captures the economic value of innovation by distinguishing breakthrough innovation from incremental discoveries.

We address several concerns regarding the innovation variables calculated based on the DWPI data set. The first one is the truncation problem caused by the fact that patents appear in the database only after they are granted. Because the lag between a patent's application year and its grant year is significant (about 2 years on average), many patent applications were still under review and had not been granted by 2015 (when we retrieved the data). To adjust the truncation bias in patent counts, we end our study period in 2010, which allows 5 more years for patents under review to be granted. Another truncation problem is related to patent citations. Patents keep receiving citations over a long period (e.g., 60 years) but we only observe citations received up to 2015. Following Hall, Jaffe, and Trajtenberg (2001), we address the truncation bias in citation counts by scaling the number of citation counts by the mean citation counts of the patent in the technology groups to which the patent belongs.

Second, we avoid the double counting problem, that is, a firm may submit patent applications to and be granted patents by more than one patenting authority based on the same invention. The DWPI database allows us to retrieve patents that are based on the same invention and are granted by all patenting authorities. For the same invention's patents, we keep the record of the earliest grant date and count the number of unique patents.

The third issue is the right skewness of the distribution of patent grants and future citations in our sample with its median at 0 . This observation is similar to what has been 
documented in the innovation literature (e.g., Acharya et al. (2014), Seru (2014), and Tian and Wang (2014)). To address the right skewness of patent and citation count distributions, we winsorize these two variables at the 99th percentile and then use the natural logarithms of patents and citations as our main innovation measures. To avoid losing firm-year observations with 0 patents or citations, we add 1 to the actual patent values before taking the natural logarithm.

\section{Institutional Ownership}

Following the literature on institutional investors (e.g., Gompers and Metrick (2001), Aggarwal et al. (2011)), we use institutional ownership at the latest report date of a calendar year and construct ownership variables as follows. Foreign institutional ownership (FIO) is the sum of shares held by all institutions domiciled in a different country from where the firm's stock is listed, as a percentage of the firm's total number of shares outstanding. We set FIO to 0 if a stock is not held by any foreign institution. Similarly, domestic institutional ownership (DIO) is the sum of shares held by all institutions domiciled in the same country as the one where the firm's stock is listed, as a percentage of the firm's total number of shares outstanding. We set DIO to 0 if a stock is not held by any domestic institution.

\section{Control Variables}

Following the literature on innovation, we control for a full set of firm and country characteristics that can affect a firm's innovation output. At the firm level, we use firm size $(\ln (\mathrm{SALE}))$, firm age $(\ln (\mathrm{AGE}))$, investments in intangible assets (RD), capital expenditures (CAPEX), asset tangibility (PPE), leverage (LEV), profitability (ROA), financial constraints (the Kaplan and Zingales's (KZ) (1997) index), and growth opportunities (TOBINS_Q). We also include industry concentration (the Herfindahl index (HHI)) and the squared Herfindahl index $\left(\mathrm{HHI}^{2}\right)$ to mitigate the nonlinear effects of product market competition on innovation output 
(Aghion et al. (2005)). In addition, we add the percentage of foreign sales in total sales (FSALE) as a firm-level control variable because MacGarvie (2006) suggests that a firm's innovation may be related to its export and import markets. Last, we also control for insider ownership (INSIDE) because managers may have stronger incentives and greater power to pursue innovative projects when insider ownership increases. We winsorize all firm-level variables at the 1st and 99th percentiles to eliminate the effects of outliers.

At the country level, we adopt several controls drawn from the literature that may be related to firm innovation. Specifically, we follow Aghion, Howitt, and Prantl (2015) to control for the patent regulatory environment by using the patent right protection index of Park (2008) (P_INDEX). We also use 2 dimensions of worldwide governance indicators, namely, the rule of law (RULE) and the government effectiveness (GOODGOV) constructed by Kaufmann, Kraay, and Mastruzzi (2011), as additional controls for country-level institutions. As Hsu et al. (2014) find that financial development is related to innovation, we control for equity market development, using the ratio of a country's stock market capitalization to its gross domestic product (GDP) (EQUITY), and credit market development, which is the ratio of a country's domestic credit to its GDP (CREDIT). Finally, we follow Acharya and Subramanian (2009) to control for a country's GDP per capita (ln(GDP)) and its levels of exports (EXPORT) and imports (IMPORT), defined as the percentages of exports and imports to its GDP, respectively. Appendix B provides detailed variable definitions.

\section{Summary Statistics}

Table 1 presents sample statistics. Panel A of Table 1 reports the means of innovation measures and institutional ownership by economy. PATENT refers to the total number of patent applications that are filed by a firm and are eventually granted in a year. CITEPAT is the total 
number of citations received by each patent. Of all the economies in the sample, Japan has the largest number of firms (1,309), followed by Taiwan (594), Korea (591), and Canada (246). An average firm in the entire sample has about 16 patents granted per year and about 27 citations received by its patents. Firms in Japan have the largest number of patents per year (25), followed by firms in Germany (21), Korea (18), Netherlands (15), Taiwan (12), and Switzerland (12). The pattern is broadly similar for citations. On average, a firm in a developed economy has a larger number of both patents and citations (17 and 28, respectively) than the one in an emerging economy (12 and 25, respectively). For institutional ownership, an average firm in a developed economy has an FIO that is just about the same as DIO (5.1\% and 5.0\%, respectively), whereas the FIO of firms in an emerging economy is substantially higher than their DIO (3.6\% vs. 0.7\%); for the entire sample, FIO is generally greater than DIO.

\section{INSERT TABLE 1 ABOUT HERE}

Panel B of Table 1 presents the summary statistics of firm and country characteristics. On average, a firm has a book value of assets of $\$ 315.7$ million, an R\&D to asset ratio of $3.2 \%$, a capital expenditure-to-asset ratio of 5.5\%, a PPE-to-asset ratio of $28.6 \%$, a leverage ratio of $21.3 \%$, an ROA of 7.4\%, and a TOBINS_Q of 1.57. The average length of time that a firm has been listed on a stock exchange is 14.5 years.

\section{Baseline Regression Results}

To examine the relation between foreign institutional ownership and firm innovation, we estimate various forms of the following model using pooled ordinary least squares (OLS) regressions:

$$
\begin{gathered}
\operatorname{INNOVATION~}_{i j t=\alpha}=\alpha+\beta_{1} \mathrm{FIO}_{i j t-1}+\beta_{2} \mathrm{DIO}_{i j t-1}+\gamma^{\prime} \mathrm{X}_{i j t-1}+\phi_{i}+\psi_{k}+\omega_{j} \\
+\varphi_{t}+\varepsilon_{i j t},
\end{gathered}
$$


where $i, k, j$, and $t$ refer to firm, industry, country, and year, respectively. The dependent variable (INNOVATION) captures firm innovation outcomes: the natural logarithm of 1 plus the number of patents $(\ln ($ PATENT) $)$ reflects innovation quantity; the natural logarithm of 1 plus the number of citations per patent $(\ln ($ CITEPAT $))$ captures innovation quality. We measure both foreign and domestic institutional ownership in year $t-1$. X denotes a vector of firm and country characteristics as discussed in Section II.B.3, which are measured in year $t-1$. We include year fixed effects $(\varphi)$ and firm fixed effects $(\phi)$ (or industry fixed effects $(\psi)$ and country fixed effects $(\omega))$ in various specifications. In all regressions, we report in parentheses robust standard errors clustered at the firm level.

Columns 1 and 2 of Table 2 report the results from pooled OLS regressions controlling for industry, country, and year fixed effects. The coefficient estimates on FIO are positive and significant at the $1 \%$ level across all specifications, suggesting a positive relation between foreign institutional ownership and innovation output. In terms of economic significance, a coefficient estimate of $0.010(0.014)$ in model 1 (model 2) suggests that an increase in foreign institutional ownership from the 25th percentile to the 75 th percentile of its distribution is associated with a $5.6 \%(7.8 \%)$ increase in the number of patents (citations per patent) in the following year. ${ }^{12}$ This result is economically significant.

\section{INSERT TABLE 2 ABOUT HERE}

While the pooled OLS regression results show a positive association between foreign institutional ownership and firm innovation, one concern is that these results could be driven by omitted variables. To alleviate this concern, we include firm fixed effects (and drop industry and

\footnotetext{
12 This way of quantifying the size of the effect of foreign institutional ownership is consistent with several studies on institutional ownership, such as Chung and Zhang (2011) and Wahal and McConnell (2000).
} 
country fixed effects as they do not vary within a firm) in the regressions and report the results in columns 3 and 4 of Table 2. Firm fixed effects absorb time-invariant unobservable firm characteristics that affect both foreign institutional ownership and firm innovation. Once again, we find that the coefficient estimates on FIO remain positive and significant at the $1 \%$ level in all specifications. The magnitudes of FIO coefficient estimates become slightly smaller in columns 3 and 4 but are still comparable to those in columns 1 and 2. This evidence suggests that our baseline finding is not driven by time-invariant unobservable firm characteristics.

Regarding firm-level control variables, the coefficient estimates on DIO are not uniformly significant across different model specifications, suggesting that there is no clear evidence for the effect of domestic institutional investors on firm innovation in non-U.S economies. One possible explanation for this result is that domestic institutional investors in nonU.S. economies may not satisfy the model assumptions of Aghion et al (2013), that is, they are weak at monitoring managers and do not effectively provide managers with insurance against failure. This argument is generally supported by the existing literature. ${ }^{13}$

${ }^{13}$ For example, Douma, George, and Kabir (2006) document that domestic institutional investors in India are predominantly government-owned, which significantly reduces their monitoring incentives due to several problems, for example, the government's nominees on the board are typically bureaucrats with minimal expertise in corporate matters. Similarly, Ahmadjian and Robbins (2005) document that Japanese institutional investors are less likely to exercise exit or voice because, as compared with foreign investors, they have very different interests and relationships with the companies whose shares they hold. Trust banks, usually close affiliates of commercial banks, are unlikely to do anything to undermine the banks' interests. Pension funds are hesitant to make demands on suppliers or customers. Life insurance companies, among the largest shareholders in the Japanese economy, tend to make money by selling insurance to employees of corporations in which they have ownership stakes. Banks are also unlikely to promote restructuring actively. 
For other firm-level control variables, the coefficient estimates on INSIDE are positive and significant in firm fixed effects regressions, which suggests that insider ownership is positively associated with firm innovation. Larger and older firms are associated with higher innovation output. Firms with higher capital expenditures have more innovation output. Firms with higher leverage are associated with lower innovation output. Financial constraints are negatively related to innovation output. All these results are consistent with earlier work (e.g., see Hall and Lerner (2010) for a survey).

As for country-level control variables, firms in countries with stronger patent regulatory environments are associated with higher innovation output. Similarly, firms located in countries with a higher government effectiveness index or with developed stock markets have higher innovation output. We find weaker evidence for the effect of exports and imports and GDP per capita on firm innovation.

We conduct a few robustness checks. First, because Japanese and Taiwanese firms are much larger in the number of firms than the rest of our sample firms, we exclude firms in these two economies from the regressions. We continue to find a positive relation between foreign institutional ownership and firm innovation. We next use a dummy variable to capture large foreign institutional ownership, which equals 1 if foreign institutional ownership is greater than $5 \%$, and 0 otherwise. We find that foreign institutional investors holding more than $5 \%$ of equity ownership in a firm are positively related to firm innovation. We report these results in Table A1 and Table A2 in the Internet Appendix (available at www.jfqa.org).

Overall, our baseline regression results suggest a positive relation between foreign institutional ownership and firm innovation, consistent with our hypothesis that foreign institutional ownership enhances firm innovation. 


\section{Identification Attempts}

Our evidence so far suggests a positive relation between foreign institutional ownership and firm innovation. While our results are robust to the inclusion of firm fixed effects that absorb time-invariant unobservables, the finding may still be subject to endogeneity concerns, because time-varying unobservable firm characteristics omitted from the regression could bias the inference. Reverse causality is another concern. It is possible that firms with high innovation potential attract foreign institutional investors. Hence, the direction of causality goes from innovation to foreign institutional ownership. In this section, we attempt to address these identification concerns by using 2 identification strategies: a DID approach and an instrumental variable approach.

\section{A. Difference-in-Differences Approach}

Our first identification strategy is to exploit a quasi-natural experiment that generates plausibly exogenous variation in foreign institutional ownership: the passage of the U.S. Jobs and Growth Tax Relief Reconciliation Act (JGTRRA) of 2003. The JGTRRA substantially lowered dividend tax rates (from $38.6 \%$ to $15 \%$ ) not just for U.S. firms but also for firms domiciled in countries that have tax treaties with the United States. Dividends from firms in nontreaty countries, however, remain taxable at the ordinary personal income tax rate after the JGTRRA (e.g., 35\% for the top income tax bracket). Therefore, non-treaty economies, which include Brazil, Hong Kong, Singapore, and Taiwan, do not receive this favorable tax treatment. ${ }^{14}$ We then use a DID approach that compares the innovation output of treatment firms with that of

\footnotetext{
${ }^{14}$ The list of non-treaty economies also includes Argentina, Chile, Colombia, Jordan, Malaysia, Peru, and
} Sri Lanka. 
control firms before and after the passage of the JGTRRA that causes an exogenous shock to foreign institutional ownership.

The passage of the JGTRRA appears to be a good candidate for a quasi-natural experiment that generates plausibly exogenous variation in foreign institutional ownership for non-U.S. firms in our sample. Because the JGTRRA was designed to lower dividend tax rates for both U.S. firms and firms domiciled in foreign countries that have tax treaties with the United States, it is unlikely to be designed to directly affect the innovation output of non-U.S. firms. Regarding the reverse causality concern, we do not expect the change in future innovation to affect the change in foreign institutional ownership brought about by the passage of the JGTRRA. We use the DID approach to compare the innovation output of the treatment and control firms 3 years before (2000-2002) and 3 years after (2004-2006) the passage of the JGTRRA.

To select treatment firms, we first require that these firms are domiciled in tax treaty countries and pay dividends in the year prior to the passage of the JGTRRA of 2002. This filter leaves us with 1,693 treatment firms. To select control firms, we require firms to be domiciled in non-treaty countries and also pay dividends in the year prior to the JGTRRA. We end up with 228 control firms. We then match each control firm with 5 treatment firms using the nearest neighbor propensity score matching algorithm. Specifically, we estimate a probit model for observations in the year immediately preceding the passage of the JGTRRA. The dependent variable equals 1 for firm-year observations of the treatment group, and 0 for those of the control group. The probit regression has the same set of independent variables as the control variables in the baseline OLS regressions, which include firm- and country-level time-varying controls as well as industry fixed effects. 
In addition, since the JGTRRA directly affects U.S. institutional investors, we divide foreign institutional ownership into U.S. foreign institutional ownership (FIOus) and non-U.S. foreign institutional ownership (FIONONUs). We include 2 innovation growth variables (i.e., the growth in the number of patents, GROWTHPATENT, and the growth in the number of citations per patent, GROWTHCITATION), both computed over the 3-year period before the passage of the JGTRRA, in the regressions to ensure the satisfaction of the parallel trend assumption, which is a key identifying assumption of the DID approach. ${ }^{15}$ We end up with 456 unique treatment firms and 228 unique control firms. ${ }^{16}$

Because the validity of the DID depends on the parallel trend assumption, we do 3 diagnostic tests to verify that this assumption is not violated. In the first diagnostic test, we report, in Panel A of Table 3, the univariate comparisons between pre-JGTRRA's innovation growth variables of treatment firms and those of control firms and their corresponding $t$ statistics. Pre-JGTRRA innovation growth variables are not significantly different between treatment and control firms. These results suggest that there is no observable pre-JGTRRA trend

15 This assumption states that in the absence of treatment (the passage of the JGTRRA in our setting), the observed DID estimator is 0 . The parallel trend assumption does not require the level of innovation variables to be the same between the treatment and the control firms over the two periods before and after the passage of the JGTRRA, because these distinctions are differenced out in the estimation. Instead, this assumption requires similar pre-JGTRRA trends in innovation variables for both the treatment and the control groups.

${ }^{16}$ Because we require treatment and control firms to pay dividends, the DID sample is different from our baseline sample. To check whether our baseline results continue to hold in this DID sample, we reestimate the baseline regressions in this sample, and find a positive effect of foreign institutional ownership on firm innovation. We report the results in Panel A of Table A3 in the Internet Appendix. 
in innovation outcomes between the two groups of firms, suggesting the satisfaction of the parallel trend assumption.

In the second diagnostic test, we plot the average logarithm number of patents (citations per patent) for treatment and control firms over a 7-year period around the passage of the JGTRRA in Graph A (B) of Figure 1. As one can observe, the two lines trend closely in parallel in the years leading up to the passage of the JGTRRA, which suggests the satisfaction of the parallel trend assumption. In addition, after the passage of the JGTRRA, the line representing treatment firms begins to trend upward across the line representing control firms, suggesting that treatment firms experience an increase in innovation output.

In the third test, we reestimate the probit model, restricted to the matched sample, and find that the coefficient estimates of the pre-JGTRRA innovation growth variables (GROWTHPATENT and GROWTHCITATION) are not statistically significant. We report this test in Table A4 of the Internet Appendix. Overall, these diagnostic tests suggest that the propensity score matching process reasonably removes meaningful observable differences in the covariates between treatment and control firms.

\section{INSERT TABLE 3 ABOUT HERE}

Panel B of Table 3 presents the results of the univariate DID test. We compute DID estimators for innovation variables by first subtracting the average number of patents (citations) over the 3-year period preceding the passage of the JGTRRA from the average number of patents (citations) over the 3-year period post JGTRRA for each treatment and control firm. We then average the difference over the two groups and report the results in columns 1 and 2, respectively. In columns 3 and 4, we report the DID estimates and the corresponding $t$-statistics with the null hypothesis that the DID estimates are 0 , respectively. 
Results in columns 3 and 4 of Panel B show that the DID estimators are positive and significant at the $1 \%$ level, suggesting that the increase in innovation output is significantly larger for the treatment group than for the control group during the period from 3 years before to 3 years after the passage of the JGTRRA. The magnitudes of the DID estimates are economically significant as well. For example, the DID estimate on $\ln ($ PATENT) is 0.099 , suggesting that treatment firms experience an increase of $11 \%$ in $\ln (\mathrm{PATENT})$ relative to the mean $\ln (\mathrm{PATENT})$ of control firms (0.853) surrounding the passage of the JGTRRA. Similarly, the DID estimator for $\ln$ (CITEPAT) is 0.123 , indicating that treatment firms experience an increase of $14 \%$ in $\ln ($ CITEPAT) relative to the mean $\ln ($ CITEPAT $)$ of control firms $(0.850)$ surrounding the passage of the JGTRRA.

Next, we perform the DID tests in a multivariate regression framework by estimating the following model:

$$
\operatorname{INNOVATION}_{i t}\left(\mathrm{FIO}_{\mathrm{US}_{i t}}\right)=\alpha+\beta \mathrm{TREAT}_{i} \times \mathrm{POST}_{t}+\gamma^{\prime} X_{i t-1}+\phi_{i}+\varphi_{t}+\varepsilon_{i t},
$$

where the dependent variable INNOVATION captures firm innovation outcomes: the natural logarithm of 1 plus the number of patents $(\ln (\mathrm{PATENT}))$; the natural logarithm of 1 plus the number of citations received by each patent $(\ln ($ CITEPAT)). The dependent variable FIOus captures U.S. foreign institutional ownership. TREAT is a dummy variable that equals 1 for treatment firms, and 0 for control firms. POST is a dummy variable that equals 1 if the fiscal year is after 2003, and 0 otherwise. $X$ consists of non-U.S. foreign institutional ownership and a vector of firm- and country-level control variables used in equation (1). $\phi_{i}$ and $\varphi_{t}$ represent firm fixed effects and year fixed effects, respectively. ${ }^{17}$ The coefficient estimate on TREAT $\times$ POST is

\footnotetext{
${ }^{17}$ TREAT and POST are absorbed by firm fixed effects and year fixed effects.
} 
the DID estimator that captures the causal effect of U.S. foreign institutional ownership on firm innovation. ${ }^{18}$

Panel C of Table 3 reports the regression results estimating equation (2) with standard errors clustered at the firm level. In models 1 and 2, where the dependent variables are FIOus, the coefficient estimates on TREAT $\times$ POST are positive and statistically significant, which suggests that treatment firms, on average, experience an increase in U.S. foreign institutional ownership following the passage of JGTRRA. For example, a coefficient estimate of 1.501 in model 1 suggests that U.S. foreign institutional ownership in treatment firms is $1.5 \%$ higher than that in control firms subsequent to the passage of the JGTRRA. In models 3-6, where the dependent variables are $\ln (\mathrm{PATENT})$ or $\ln (\mathrm{CITEPAT})$, the coefficient estimates on TREAT $\times$ POST are positive and significant at the $1 \%$ level, which suggests that treatment firms, on average, experience a larger increase in innovation output than control firms following the passage of the JGTRRA. A coefficient estimate of 0.091 (0.115) in model 4 (model 6) suggests that, compared with the control group, the treatment group experiences an increase of $9.1 \%$ $(11.5 \%)$ in the number of patents (the number of citations per patent).

To ensure that our DID test results are robust, we conduct a few more tests. First, because it is plausible that firms anticipate the passage of the JGTRRA, our selection of treatment and control firms that pay dividends 1 year in advance of the event could still be subject to potential endogeneity. To address this concern, we require that treatment and control firms pay dividends

\footnotetext{
${ }^{18}$ When we run a similar regression with $\mathrm{FIO}_{\text {NONUS }}$ being the dependent variable, we find that the
} coefficient estimate on TREAT $\times$ POST is not significant. We report the results in Panel B of Table A3 in the Internet Appendix. 
2 years, as compared to 1 year, prior to the passage of the JGTRRA (i.e., starting from 2001) and repeat the DID analysis. Our DID results do not change qualitatively. We report these results in Table A5 in the Internet Appendix.

Second, if the passage of the JGTRRA affects U.S. foreign institutional ownership of dividend-paying stocks in treaty countries, then this event should not affect the U.S. institutional ownership of non-dividend paying stocks in these treaty countries. As a result, the innovation output of non-dividend paying stocks in treaty countries should not differ significantly from that of non-dividend paying stocks in non-treaty countries surrounding the event. We thus conduct one placebo test by selecting treatment and control firms that do not pay dividends in 2002 and perform a similar DID analysis. We find that the DID estimators are statistically insignificant, which suggests that the event does not have a significant effect on the innovation output of nondividend paying stocks in both treaty and non-treaty countries. This placebo test indicates that our main DID test results are unlikely to be driven by chance.

Third, we argue that if the JGTRRA affects U.S. institutional investors, there should be no significant difference in the innovation output between dividend-paying firms that do not have U.S. foreign institutional ownership in treaty countries and those in non-treaty countries. We thus conduct a second placebo test by selecting treatment and control firms that have zero U.S. institutional ownership in 2002. We find insignificant DID estimators, which supports our conjecture. We report the results for the above two placebo tests in Table A6 in the Internet Appendix.

\section{B. Instrumental Variable Approach}

The use of the passage of the JGTRRA in the DID approach is not completely free of concerns. For example, even though Desai and Dharmapala (2011) find that following the 
passage of the JGTRRA, U.S. institutions tilt their portfolio allocations to dividend paying equities in treaty countries, Ammer, Holland, Smith, and Warnock (2012) document that this finding becomes weaker after controlling for international cross-listing. It is plausible that the passage of the JGTRRA reduces the cost of equity capital for innovative firms and incentivizes these firms to finance future projects through cross-listing in the United States. As a result, the passage of the JGTRRA could lead to more innovation and U.S. institutional ownership.

To further ensure that the documented results are likely to be causal, our second identification strategy is to construct an instrumental variable and use the 2-stage least squares (2SLS) approach. An ideal instrument should capture the variation in foreign institutional ownership that is exogenous to a firm's innovation output. Because the exclusion restriction of an instrument is inherently untestable, the instrument needs to be conceptually motivated.

We follow Aggarwal et al. (2011) and use the time-varying membership in the MSCI All Country World Index to create a possible exogenous variation in foreign institutional ownership. The MSCI is a free float-adjusted market capitalization weighted index that is designed to measure the global equity market performance. Launched in 1987, this index consists of 45 indices ( 24 developed and 21 emerging country indices), with coverage of about $85 \%$ of the global investable equity opportunity set. Ferreira and Matos (2008) and Leuz et al. (2010) find that MSCI membership increases the equity ownership of foreign institutional investors in the firms. We define the instrument as a dummy variable (MSCI) that equals 1 if a firm is a member of the MSCI index in year $t$, and 0 otherwise, and present the IV regression results in Table 4. The regressions control for firm- and country-level characteristics, as well as firm, industry, country, and year fixed effects in various specifications.

INSERT TABLE 4 ABOUT HERE 
To check the relevance of the instrument, in models 1 and 4 of Table 4 , we present the first-stage regression with FIO as the dependent variable and the instrument as the main independent variable. We include the same set of independent variables as those used in the baseline regressions in Table 2. The coefficient estimates on MSCI are positive and significant at the $1 \%$ level, suggesting that the MSCI dummy is positively associated with FIO. The $p$-value of the $F$-test of the instrument shown at the bottom of the table is close to 0 , indicating that the instrument is highly correlated with FIO. Based on the rule of thumb with one instrument for one endogenous variable, we are able to reject the null hypothesis that the instrument is weak. Therefore, the coefficient estimates and their corresponding standard errors in the second stage are likely to be unbiased and inferences based on them are reasonably valid. However, a caveat of the IV approach may be in order. While the above tests ensure that the MSCI dummy satisfies the relevance condition, we cannot directly test the exclusion restriction of the instrument. It is plausible that some unobservable factors affect both the inclusion of MSCI membership and foreign institutional ownership. Hence, our instrument needs to be conceptually motivated based on existing studies.

In columns 2, 3, 5, and 6 of Table 4, the coefficient estimates on the fitted (instrumented) values of FIO are positive and statistically significant at the $1 \%$ level, which suggests that foreign institutional ownership appears to have a positive effect on innovation output. The economic effect is sizable. A coefficient estimate of 0.037 (0.046) in column 5 (column 6) suggests that an increase in the instrumented foreign institutional ownership from the 25 th percentile to the 75 th percentile of its distribution leads to a $21 \%(26 \%)$ increase in the number 
of patents (citation per patent). ${ }^{19}$ If we compare these coefficient estimates with the OLS results in Table 2, these coefficient estimates from the 2SLS analyses are substantially larger, which suggests that the OLS results underestimate the positive effects of foreign institutional ownership on firm innovation.

In summary, consistent with our hypothesis, our identification tests based on both the DID approach and the IV approach provide evidence that the effect of foreign institutional ownership on firm innovation appears to be causal. One caution, however, is that, because neither the passage of the JGTRRA nor the MSCI index membership is perfectly exogenous to innovation output and both strategies have their own limitations, we cannot completely rule out the possibility that our main results are driven by endogeneity in foreign institutional ownership. Therefore, one needs to be cautious when interpreting and generalizing our results.

\section{Possible Economic Mechanisms}

In this section, we explore three possible underlying economic mechanisms through which foreign institutional investors promote firm innovation. Although we attempt to identify different economic mechanisms that underlie the positive effect of foreign institutional ownership on innovation, we acknowledge that these underlying mechanisms are not necessarily mutually exclusive, and if anything, may jointly contribute to the positive effect of foreign institutions on innovation.

\footnotetext{
${ }^{19}$ Note that the coefficient estimates on LEV and TOBINS_Q become statistically insignificant while they are significant in the OLS regressions. One plausible reason is that the effects of LEV and TOBINS_Q on firm innovation are driven by foreign institutional investors. Once "cleaned" foreign institutional ownership (through instrumented FIO) is included in the regressions, we are better able to capture the effects of foreign institutional investors on firm innovation, which absorbs the effects of LEV and TOBINS_Q on innovation.
} 


\section{A. Monitoring}

Due to agency problems caused by the separation of ownership and control, a potential moral hazard problem emerges in which firm managers overinvest in routine tasks that are less challenging to enjoy private benefits (Hart (1983), Bertrand and Mullainathan (2003)). The theory of Stein (1988) shows that managers could underinvest in innovative projects due to their being high-risk in nature and not generating predictable returns in the short run.

Monitoring by institutional investors is thus an important governance mechanism to mitigate managerial myopia. Compared with small investors who are relatively less informed, institutional investors are better able to provide effective and active monitoring due to their large ownership stakes in firms, as well as their ability to exploit the economy of scale in information production and processing (e.g., Shleifer and Vishny (1986), Grossman and Hart (1988), and Gillan and Starks (2000), (2003)). However, not all institutions are actively engaged in monitoring. For instance, Bushee (1998) finds that institutional investors with short-term investments induce managerial myopia while institutions with long-term investments reduce managers' myopic behavior. Chen et al. (2007) show that long-term institutions focus more on monitoring and influencing efforts than on trading. They also find that independent institutions are more inclined to gather information and get actively involved in the corporate decisions of firms in which they invest, while grey institutions are more likely to hold shares without intervening in firms' business. ${ }^{20}$

We thus postulate that if monitoring by foreign institutional investors contributes to increases in firm innovation, then those foreign institutions that have strong incentives to

${ }^{20}$ Chen et al. (2007) define mutual fund managers and investment advisors as "independent institutions" and bank trusts, insurance companies, pension funds, and endowments as "grey" institutions. 
monitor, that is, independent or long-term foreign institutions, should play a more significant role in promoting firm innovation. As such, we separate foreign institutional ownership into 2

components: ownership by independent (or long-term) foreign institutional investors and by grey (or short-term) foreign institutional investors. We then examine the effects of these types of foreign institutions on firm innovation.

Similar to our main analysis, we use OLS regressions with firm fixed effects and the DID analysis to test our conjecture. We present the results in Table 5. In Panel A, we reestimate the baseline OLS regressions but distinguish between independent and grey institutions, as well as long-term and short-term institutions. Columns 1 and 3 focus on 2 key independent variables: the percentage of shares held by independent institutions (FIOINDEPENDENT), such as mutual funds and investment advisors, and the percentage of shares held by grey institutions (FIOGREY), such as bank trusts, insurance companies, and other institutions. The coefficient estimates on FIOINDEPENDENT are positive and significant at the $1 \%$ or $5 \%$ level in these models. However, the coefficient estimates on FIOGREY are statistically insignificant. These results imply that the positive effect of foreign institutional investors on firm innovation is largely driven by independent institutions, who are more actively engaged in monitoring.

\section{INSERT TABLE 5 ABOUT HERE}

In columns 2 and 4 of Panel A of Table 5, we classify foreign institutions into long-term and short-term institutional investors based on investment horizon and re-run the regressions by focusing on 2 independent variables, FIOLONG_TERM (the percentage of shares held by foreign institutions for more than 1 year) and FIOSHORT_TERM (the percentage of shares held by foreign institutions for less than 1 year). The coefficient estimates on FIOLONG_TERM are positive and significant at the $1 \%$ level in both models, while the coefficient estimates on FIOSHORT_TERM are 
insignificant. This evidence suggests that the positive effect of foreign institutional ownership on firm innovation is mainly driven by long-term foreign institutional investors.

In addition to these firm fixed effects regressions, we conduct the DID test in Panel B of Table 5. We perform the DID analysis for different types of institutions using the same procedures discussed in Section IV.A. When undertaking the propensity score matching algorithm, we use the same set of matching variables as before except that the equity ownership of U.S. foreign institutions (FIOus) is replaced with the equity ownership of a certain type of U.S. foreign institution (independent, grey, long-term, or short-term U.S. foreign institutions). Using this matching procedure, we assume that the treatment group experiences, to some extent, exogenous changes in equity ownership for each type of U.S. foreign institution following the passage of the JGTRRA.

After conducting the matching procedure for each type of U.S. foreign institution, we compute the DID estimators for innovation variables in the same way as in Section IV.A. We find that the DID estimates for independent or long-term U.S. foreign institutions are positive and significant at the $1 \%$ or $5 \%$ levels, while the DID estimates for grey or short-term U.S. foreign institutions are largely insignificant. These results once again suggest that the positive effect of foreign institutional ownership on firm innovation is primarily driven by independent or long-term foreign institutions.

Overall, this subsection shows that independent or long-term foreign institutional investors, who actively monitor firms, play a crucial role in motivating innovation. This evidence suggests that intensive monitoring by foreign institutional investors appears to be a possible underlying mechanism through which foreign institutional investors enhance firm innovation.

\section{B. Insurance}


Economics and psychology literature on motivating innovation has shown that while the standard pay-for-performance incentive scheme has positive effects on motivating effort in routine tasks, it may actually undermine performance in tasks that require creativity and exploration (Glucksberg (1962), Manso (2001)). Incentive schemes that motivate innovation must exhibit substantial tolerance for failure, implying that compensation schemes that are less sensitive to performance can, to some extent, motivate innovation better (Holmstrom (1989), Ederer and Manso (2013)).

Aghion et al. (2013) find that managerial turnover in U.S. firms is less sensitive to firm performance in the presence of institutional investors, consistent with the argument that institutional investors provide partial insurance to managers with career or reputational concerns against failure risks arising from their intensive innovation activities. Ederer and Manso (2013) show that a manager's incentive to innovate is undermined by the threat of contractual termination in an experimental study. Based on these studies, we argue that if foreign institutional investors promote innovation by insulating managers from punishment for innovation failures, CEO turnover and compensation should be less sensitive to performance in the presence of foreign institutional investors.

To test this conjecture, we collect CEO turnover data from the BoardEx database and match them with our sample firms for the period from 2000 to 2010. We are able to match 167 CEO turnover events in our sample firms and end up with 755 firm-year observations in the matched sample. Similarly, we collect CEO compensation data from BoardEx and match them with our sample firms. The resulting matched sample contains 785 firm-year observations.

To test the effect of foreign institutional ownership on the CEO turnover-performance sensitivity, we follow Aghion et al. (2013) and estimate the following linear probability model: 


$$
\begin{aligned}
\mathrm{CEO}_{-} \mathrm{TURN}_{i t}= & \alpha+\beta_{1} \Delta \mathrm{ROA}_{i t-1}+\beta_{2} \mathrm{FIO}_{i t-1} \times \Delta \mathrm{ROA}_{i t-1}+\beta_{3} \mathrm{DIO}_{i t-1} \times \Delta \mathrm{ROA}_{i t-1}+ \\
& \beta_{4} \mathrm{FIO}_{i t-1}+\beta_{5} \mathrm{DIO}_{i t-1}+\beta_{6} \ln (\mathrm{MCAP})_{i t-1}+\phi_{i}+\varphi_{t}+\varepsilon_{i t}
\end{aligned}
$$

where $i$ and $t$ refer to firm and year, respectively. CEO_TURN is a dummy variable that equals 1 if the CEO leaves firm $i$ during year $t$, and 0 otherwise. $\triangle \mathrm{ROA}$ is the change in profitability in percentage points. $\ln (\mathrm{MCAP})$ is the natural logarithm of market capitalization. The specification includes firm fixed effects $(\phi)$ and year fixed effects $(\varphi)$.

To examine the effect of institutional ownership on pay-for-performance sensitivity, we follow Hartzell and Starks (2003) and estimate the following model:

$$
\begin{aligned}
\Delta{\text { CEO_CASH }(\mathrm{TOTAL})_{i t}=} & \alpha+\beta_{1} \Delta \mathrm{WEALTH}_{i t-1}+\beta_{2} \mathrm{FIO}_{i t-1} \times \Delta \mathrm{WEALTH}_{i t-1}+ \\
& \beta_{3} \mathrm{DIO}_{i t-1} \times \Delta \mathrm{WEALTH}_{i t-1}+\beta_{4} \mathrm{FIO}_{i t-1}+\beta_{5} \mathrm{DIO}_{i t-1}+ \\
& \beta_{6} \ln (\mathrm{MCAP})_{i t-1}+\phi_{i}+\varphi_{t}+\varepsilon_{i t},
\end{aligned}
$$

where $i$ and $t$ refer to firm and year, respectively. $\triangle$ CEO_CASH (TOTAL) is the change in the level of cash and bonus compensation (total compensation, which includes cash, bonus, equity, option, and long-term incentive plans). $\triangle \mathrm{WEALTH}$ is the change in market value from period $t-1$ to $t$. The specification includes firm fixed effects $(\phi)$ and year fixed effects $(\varphi)$.

To address the endogeneity concern, we first estimate regressions with firm fixed effects to absorb time-invariant unobservable firm characteristics. Panel A of Table 6 reports the results estimating equations (3) and (4). Model 1 presents the results estimating equation (3). Consistent with the previous literature, we observe that a higher profitability growth is associated with a lower probability that the CEO will be fired, as suggested by a negative and significant coefficient estimate on $\triangle \mathrm{ROA}(-0.011)$. More importantly, the coefficient estimate on the interaction term, $\mathrm{FIO} \times \Delta \mathrm{ROA}$, is positive and significant at the $5 \%$ level $(0.001)$, which suggests that the negative effect of performance on CEO turnovers is mitigated by foreign institutional 
ownership. In other words, in firms with greater foreign institutional ownership, CEO performance-turnover sensitivity is lower. In terms of economic significance, an increase in foreign institutional ownership from the 25 th percentile to the 75 th percentile of its distribution leads to a decrease in the sensitivity of CEO turnover to firm performance from $1.1 \%$ to $0.54 \% .{ }^{21}$

Models 2 and 3 of Table 6 examine how foreign institutional ownership affects the CEO's pay-for-performance sensitivity. The dependent variable is the change in cash and bonus compensation (model 2) or the change in total compensation (model 3). Consistent with Hartzell and Starks (2003), the coefficient estimates on $\triangle$ WEALTH are positive and significant, suggesting that changes in shareholder wealth are positively related to changes in CEO compensation. More importantly, the coefficient estimates on the interaction term, FIO $\times \triangle \mathrm{WEALTH}$, are negative and significant at the $5 \%$ level in both specifications, suggesting that greater foreign institutional ownership largely weakens the CEO's pay-for-performance sensitivity.

\section{INSERT TABLE 6 ABOUT HERE}

Next, we perform a DID analysis and present the results in Panel B of Table 6. Specifically, we match CEO turnover and compensation data from the BoardEx database with

\footnotetext{
${ }^{21}$ We have both FIO and $\triangle$ ROA measured in percentage points and the sensitivity of CEO turnover to performance is $\partial \mathrm{Pr}\left(\mathrm{CEO} \_\mathrm{TURN}\right) / \partial \Delta \mathrm{ROA}=-0.011+0.001 \times \mathrm{FIO}$, where -0.011 and 0.001 are the coefficient estimates on $\triangle \mathrm{ROA}$ and FIO $\times \triangle \mathrm{ROA}$, respectively. An increase in foreign institutional ownership from the 25th percentile $(\mathrm{FIO}=0)$ to the 75 th percentile $(\mathrm{FIO}=5.585)$ of its distribution is associated with a decrease in the sensitivity of CEO turnover to performance from $1.1 \%[(-0.011+0.001 \times 0) \times 100=-1.1 \%]$ to $0.54 \%$ $[(-0.011+0.001 \times 5.585) \times 100 \cong-0.54 \%]$.
} 
the DID analysis sample as constructed in Section IV.A that has 456 treatment firms and 228 control firms. The final samples consist of 110 firm-year observations for the CEO turnover test and 121 firm-year observations for the CEO compensation test. To conduct the DID analysis for this mechanism, we estimate the following two models:

$$
\begin{aligned}
\mathrm{CEO}_{-} \mathrm{TURN}_{i t}=\quad & \alpha+\beta_{1} \Delta \mathrm{ROA}_{i t-1} \times \mathrm{TREAT}_{i} \times \mathrm{POST}_{t}+\beta_{2} \Delta \mathrm{ROA}_{i t-1} \times \mathrm{TREAT}_{i}+ \\
& \beta_{3} \Delta \mathrm{ROA}_{i t-1} \times \mathrm{POST}_{t}+\beta_{4} \Delta \mathrm{ROA}_{i t-1}+\beta_{5} \mathrm{TREAT}_{i} \times \mathrm{POST}_{t}+ \\
& \beta_{6} \ln (\mathrm{MCAP})_{i t-1}+\phi_{i}+\varphi_{t}+\varepsilon_{i t}
\end{aligned}
$$

$$
\begin{aligned}
\Delta \mathrm{CEO}_{-} \mathrm{CASH}(\mathrm{TOTAL})_{i t}= & \alpha+\beta_{1} \Delta \mathrm{WEALTH}_{i t-1} \times \mathrm{TREAT}_{i} \times \mathrm{POST}_{t}+ \\
& \beta_{2} \Delta \mathrm{WEALTH}_{i t-1} \times \mathrm{TREAT}_{i}+\beta_{3} \Delta \mathrm{WEALTH}_{i t-1} \times \\
& \mathrm{POST}_{t}+\beta_{4} \Delta \mathrm{WEALTH}_{i t-1}+\beta_{5} \mathrm{TREAT}_{i} \times \mathrm{POST}_{t}+ \\
& \beta_{6} \ln (\mathrm{MCAP})_{i t-1}+\phi_{i}+\varphi_{t}+\varepsilon_{i t},
\end{aligned}
$$

where $i$ and $t$ refer to firm and year, respectively. CEO_TURN, $\triangle$ ROA, $\Delta$ CEO_CASH (TOTAL), $\triangle$ WEALTH, TREAT, POST, and $\ln (\mathrm{MCAP})$ are defined the same way as those in equations (3) and (4). The specification includes firm fixed effects $(\phi)$ and year fixed effects $(\varphi)$. Robust standard errors are clustered at the firm level and bootstrapped with 1,000 replications.

Panel B of Table 6 reports the results estimating equations (5) and (6). Model 1 presents the results estimating equation (5). We find that the coefficient estimate on the triple interaction term, $\triangle \mathrm{ROA} \times \mathrm{TREAT} \times \mathrm{POST}$, is positive and significant at the $5 \%$ level. These results suggest that the negative effect of performance on CEO turnover is mitigated more for treatment firms than for control firms following the passage of the JGTRRA. Models 2 and 3 present the results estimating equation (6). The coefficient estimates on the triple interaction term, $\triangle$ WEALTH $\times$ TREAT $\times$ POST, are negative and significant at the $10 \%$ and the $1 \%$ levels in 
models 2 and 3, respectively. These results suggest that treatment firms' pay-for-performance sensitivity becomes weaker than that of control firms after the passage of the JGTRRA.

Overall, in this subsection we show that the sensitivities of CEO turnover and compensation to firm performance are weakened in the presence of foreign institutional investors. This finding is consistent with the argument that, by providing insurance to managers with career and reputational concerns, foreign institutional investors allow managers to focus more on long-term, risky investment in innovative projects and hence positively contribute to their investee firms' innovation output.

\section{Knowledge Spillovers}

In this subsection, we explore a third possible mechanism through which foreign institutions contribute positively to firm innovation. Besides monitoring and insurance, foreign institutions could enhance innovation through facilitating knowledge spillovers in their crossborder investment activities. Compared to domestic institutional investors, this mechanism is unique to foreign institutional investors.

Investment in knowledge creation by one party facilitates innovation by others (Jaffe et al. (2000)). Knowledge spillovers could be indirect and involve different types of stakeholders including firms, investors, customers, suppliers, competitors, and governments. The literature has suggested that the locus of innovation and knowledge circulation lies in dynamic, competencybased, business networks (Voss (2003), Walters and Buchanan (2001), and Wright and Burns (1998)). One example is that CEO network connections facilitate corporate innovation (Faleye, Kovacs, and Venkateswaran (2014)). In this regard, there is anecdotal evidence suggesting that foreign institutional investors could facilitate networks among different stakeholders. For example, Laurence Fink, the CEO of BlackRock, a leading U.S. investment management 
company with investments in over 100 countries and offices in 30 countries, including India, offered to host a global investors meeting in India in early 2015 in response to the call for investment by the Prime Minister of India, Narendra Modi, during his visit to the United States in 2014 (http://www.dnaindia.com/india/report-after-meeting-pm-narendra-modi-blackrock-ceooffers-to-host-global-investors-meet-in-india-in-2015-2022468). This example suggests that foreign institutions could facilitate knowledge spillovers through business networks by acting as a bridge between local firms and foreign firms or investors, so that they could exchange opportunities and knowledge, which then could contribute to innovation.

Knowledge spillovers can also occur within a multinational corporation. In a study of cross-border mergers and acquisitions, Ferreira et al. (2010) find that foreign institutional investors are a driving force behind cross-border mergers and acquisitions because they act as facilitators, build bridges between firms, and reduce transaction costs and information asymmetry between bidders and target acquisitions. Relatedly, Guadalupe et al. (2012) find that after being acquired by foreign acquirers, domestic firms are likely to innovate through their access to foreign technologies and widening foreign markets. Based on these two studies, a reasonable argument is that foreign institutional investors could contribute to the innovation of domestic firms through facilitating cross-border mergers and acquisitions, and ultimately, knowledge spillovers.

Along these lines, we argue that one possible channel through which foreign institutional investors promote innovation is that they facilitate knowledge spillovers from a more innovative economy to a less innovative economy. They can do so by acting as a facilitator in cross-border mergers and acquisitions, or as a bridge for a network of managers, investors, and other stakeholders of foreign and domestic firms to exchange knowledge, ideas, and opportunities, 
which, to a certain extent, contributes to investee firms' innovation. If our conjecture is supported, the innovativeness of institutional investors' home countries should play a role in firm innovation. In particular, foreign institutional investors from economies with a higher level of innovation output may affect investee firms' innovation output to a larger extent than those from economies with a lower level of innovation output, because the former can provide better advice and/or have better expertise on how to speed up knowledge transfers.

We test this hypothesis using a data set of country-level patents collected from the World Bank database. ${ }^{22}$ We construct 4 measures of country-level innovativeness for each of the 73 countries in which the institutions in our sample are domiciled. The first measure is the total number of patents applied for by all residents of a country in a year scaled by its GDP (PATENT_GDP). The second measure is the total number of patents applied for by all residents of a country in a year scaled by its total population (PATENT_POP). The third measure is the total number of patents applied for by all residents of a country in a year scaled by its total number of listed firms (PATENT_FIRMS). The last measure is the total number of patents applied for by all residents of a country in a year scaled by its market capitalization (PATENT_MCAP). We then take the average of each of these country-level innovativeness measures over the 2000-2010 period. We define an institution's home country as a high- (low-) innovation country if the country's innovation measure is above (below) the median of all 73 countries' measures. We then classify foreign institutional ownership according to whether the

${ }^{22}$ While the DWPI database contains patent information at the assignee level, it does not have detailed information on the resident country of assignees. The World Bank patent database provides aggregate country-level data on both resident and non-resident patent holders. 
institutional investors come from high-innovation countries or low-innovation countries and examine the effects of these ownership components on firm innovation.

We run OLS regressions with firm fixed effects to mitigate the endogeneity concern. We reestimate the baseline regressions but distinguish between the ownership of foreign institutional investors from high-innovation countries (FIOHIGH_INNO) and the ownership of foreign institutional investors from low-innovation countries (FIOLOw_InNo). Panel A of Table 7 presents these regression results based on the innovativeness of foreign institutional investors' home countries in which the dependent variables are $\ln$ (PATENT) (models 1-4) and $\ln (\mathrm{CITEPAT})$ (models 5-8). The results show that the coefficient estimates on FIOHIGH_INNO are positive and significant in almost all models except for model 4. The coefficient estimates on FIOLOW_INNO are insignificant in all specifications. These results suggest that the positive effect of foreign institutional ownership on firm innovation is largely driven by institutions from high-innovation foreign countries.

\section{INSERT TABLE 7 ABOUT HERE}

However, it is plausible that the innovativeness of institutional investors' home countries might be correlated with their institutional environments. To address this concern, we include country-level governance of foreign institutions, measured by the anti-self-dealing index of $\mathrm{La}$ Porta, Lopez-de-Silanes, and Shleifer (2006), in our analysis. Specifically, we classify foreign institutional investors into 4 groups according to whether a foreign institution comes from a high (low)-innovation (or governance) country. An institution's home country is defined as a high- or low-governance country if its anti-self-dealing index is above or below the median of all domiciled countries of the sample institutional investors. We classify foreign institutions into 4

groups: high-innovation and high-governance countries (FIOHIGHINNO_HIGHGOv), high-innovation 
and low-governance countries (FIOHIGHINNO_LOWGOv), low-innovation and high-governance countries (FIOLOWINNO_HIGHGOV), and low-innovation and low-governance countries (FIOLOWINNO_LOWGOV).

In Panel B of Table 7, we find that the coefficient estimates on FIOHIGHINNo_HIGHGOv are positive and significant, suggesting that foreign institutions from high-innovation and highgovernance countries positively influence firm innovation. In addition, the coefficient estimates on FIOHIGHINNo_Lowgov remain positive and significant (except for models 4 and 8), which suggests that those foreign institutions from high-innovation but low-governance countries positively affect the innovation of their investee firms. In summary, we find evidence suggesting that foreign institutions coming from high-innovation countries regardless of their governance level positively affect firm innovation.

To the extent that the United States is the most innovative country in our sample, the DID analysis reported in Panel $\mathrm{C}$ of Table 3 also provides evidence that supports this underlying economic mechanism. Specifically, the coefficient estimates on TREAT $\times$ POST, which captures the exogenous increase in U.S. foreign institutional ownership following the passage of the JGTRRA, are positive and statistically significant at the $1 \%$ level while those of FIONONUs are significant only at the marginal level. The magnitudes of these estimates on TREAT $\times$ POST are much larger (5 times larger) than those on FIONONus. These results suggest that a positive shock in foreign equity ownership of institutions coming from a more innovative country (e.g., the United States) leads to a significantly larger increase in the innovation output of investee firms.

Overall, in this subsection we show that the innovativeness of foreign institutional investors' home countries positively contributes to investee firms' innovation output, which suggests that innovation travels with foreign institutions that come from high-innovation 
countries. Hence, knowledge spillovers are a plausible mechanism through which foreign institutional investors promote innovation. ${ }^{23}$

\section{Conclusion}

We examine the effect of foreign institutional investors on firm innovation. Using firmlevel data across 26 non-U.S. economies for the 2000-2010 period, we document a positive effect of foreign institutional ownership on firm innovation. To address endogeneity concerns, we use both an instrumental variable approach and a DID approach that relies on a plausibly exogenous variation in foreign institutional ownership generated by a quasi-natural experiment, the passage of the JGTRRA. Our identification tests suggest that this positive effect is causal.

We further explore three possible underlying economic mechanisms through which foreign institutional investors promote innovation. We find that foreign institutions promote firm innovation by acting as active monitors, by providing insurance against innovation failures to firm managers with career or reputational concerns, and by promoting knowledge spillovers

\footnotetext{
${ }^{23}$ It is reasonable to argue that foreign institutional ownership affects firm innovation over a long-term
} period and how fast this effect takes place should depend on the underlying economic mechanisms. We thus extend our analysis by using 2- or 3-year instead of 1-year-ahead innovation measures as the dependent variables in the baseline regression, as well as in regressions that explore the underlying economic mechanisms. Under the monitoring mechanism, it appears that foreign institutional investors have more immediate effects on firm innovation, as the coefficient estimates on FIOINDEPENDENT and FIOLONG_TERM become less significant when the 2- or 3-year lead innovation measures are used as the dependent variables. On the other hand, in the knowledge spillover mechanism, it apparently takes foreign institutional investors longer time before they could influence firm innovation, because the coefficient estimates on $\mathrm{FIO}_{\mathrm{HIGH}_{-} \mathrm{INNO}}$ remain highly significant when the 2-year-ahead innovation measures are used as the dependent variables. We present these regression results in Table A7 in the Internet Appendix. 
from high-innovation countries. Our paper provides the first rigorous empirical study to examine the role of foreign institutional investors in motivating technological innovation outside the United States. 


\section{References}

Acharya, V. V.; R. P. Baghai; and K. V. Subramanian. "Wrongful Discharge Laws and Innovation." Review of Financial Studies, 27 (2014), 301-346.

Acharya, V. V., and K. V. Subramanian. "Bankruptcy Codes and Innovation." Review of Financial Studies, 22 (2009), 4949-4988.

Aggarwal, R.; I. Erel; M. Ferreira; and P. Matos. "Does Governance Travel Around the World? Evidence from Institutional Investors." Journal of Financial Economics, 100 (2011), $154-181$.

Aghion, P.; N. Bloom; R. Blundell; R. Griffith; and P. Howitt. "Competition and Innovation: An Inverted-U Relationship." Quarterly Journal of Economics, 120 (2005), 701-728.

Aghion, P.; P. Howitt; and S. Prantle. "Patent Rights, Product Market Reforms, and Innovation." Journal of Economic Growth, 20 (2015), 223-262.

Aghion, P.; J. Van Reenen; and L. Zingales. "Innovation and Institutional Ownership." American Economic Review, 103 (2013), 277-304.

Agrawal, A.; I. Cockburn; and J. McHale. "Gone but not Forgotten: Knowledge Flows, Labor Mobility, and Enduring Social Relationships." Journal of Economic Geography, 6 (2006), 571-591.

Ahmadjian, C. L., and G. E. Robbins. "A Clash of Capitalisms: Foreign Shareholders and Corporate Restructuring in 1990s Japan." American Sociological Review, 70 (2005), 451471.

Ammer, J.; S. B. Holland; D. C. Smith; and F. E. Warnock. "U.S. International Equity Investment." Journal of Accounting Research, 50 (2012), 1109-1139. 
Bekaert, G., and C. R. Harvey. "Emerging Equity Market Volatility." Journal of Financial Economics, 43 (1997), 29-77.

Bekaert, G., and C. R. Harvey. "Foreign Speculators and Emerging Equity Markets." Journal of Finance, 55 (2000), 565-613.

Bekaert, G.; C. R. Harvey; and C. Lundblad. "Growth Volatility and Financial Liberalization." Journal of International Money and Finance, 25 (2006), 370-403.

Bena, J.; M. A. Ferreira; P. Matos; and P. Pires. "Are Foreign Investors Locusts? The LongTerm Effects of Foreign Institutional Ownership." Journal of Financial Economics, forthcoming (2017).

Bertrand, M., and S. Mullainathan. "Enjoying the Quiet Life? Corporate Governance and Managerial Preferences." Journal of Political Economy, 111 (2003), 1043-1075.

Bradley, D.; I. Kim; and X. Tian. "Do Unions Affect Innovation?" Management Science, forthcoming (2017).

Branstetter, L. "Is Foreign Direct Investment a Channel of Knowledge Spillovers? Evidence from Japan's FDI in the United States." Journal of International Economics 68 (2006), $325-344$.

Brown, J. R.; G. Martinsson; and B. C. Petersen. "Law, Stock Markets, and Innovation." Journal of Finance, 68 (2013), 1517-1549.

Burkart, M.; D. Gromb; and F. Panunzi. "Large Shareholders, Monitoring, and the Value of the Firm." Quarterly Journal of Economics, 112 (1997), 693-728.

Bushee, B. J. "The Influence of Institutional Investors in Myopic R\&D Investment Behavior." Accounting Review, 73 (1998), 305-333. 
Carayannis, E. G.; E. T. Samara; and Y. L. Bakouros. Innovation and Entrepreneurship: Theory, Policy, and Practice. London, UK: Springer (2015).

Chang, X.; R. D. McLean; B. Zhang; and W. Zhang. "Innovation and Productivity Growth: Evidence from Global Patents." SSRN Working Paper Series (2015).

Chari, A.; P. B. Henry; and D. Sasson. "Capital Market Integration and Wages." American Economic Journal: Macroeconomics, 4 (2012), 102-32.

Chemmanur, T. J.; E. Loutskina; and X. Tian. "Corporate Venture Capital, Value Creation, and Innovation." Review of Financial Studies, 27 (2014), 2434-2473.

Chen, J.; W. S. Leung; and K. P. Evans. "Are Employee-Friendly Workplaces Conducive to Innovation?" Journal of Corporate Finance, 40 (2016), 61-79.

Chen, X.; J. Harford; and K. Li. "Monitoring: Which Institutions Matter?" Journal of Financial Economics, 86 (2007), 279-305.

Chung, K. H., and H. Zhang. "Corporate Governance and Institutional Ownership." Journal of Financial and Quantitative Analysis, 46 (2011), 247-273.

Cornaggia, J.; Y. Mao; X. Tian; and B. Wolfe. "Does Banking Competition Affect Innovation?" Journal of Financial Economics, 115 (2015), 189-209.

Desai, M. A., and D. Dharmapala. "Dividend Taxes and International Portfolio Choice." Review of Economics and Statistics, 93 (2011), 266-284.

Douma, S.; R. George; and R. Kabir. "Foreign and Domestic Ownership, Business Groups, and Firm Performance: Evidence from a Large Emerging Market." Strategic Management Journal, 27 (2006), 637-657.

Ederer, F., and G. Manso. "Is Pay for Performance Detrimental to Innovation?" Management Science, 59 (2013), 1496-1513. 
Faleye, O.; T. Kovacs; and A. Venkateswaran. "Do Better-Connected CEOs Innovate More?" Journal of Financial and Quantitative Analysis, 49 (2014), 1201-1225.

Fang, V. W.; M. Maffett; and B. Zhang. "Foreign Institutional Ownership and the Global Convergence of Financial Reporting Practices." Journal of Accounting Research, 53 (2015), 593-631.

Fang, V. W.; X. Tian; and S. Tice. "Does Stock Liquidity Enhance or Impede Firm Innovation?" Journal of Finance, 69 (2014), 2085-2125.

Ferreira, M. A.; M. Massa; and P. Matos. "Shareholders at the Gate? Institutional Investors and Cross-Border Mergers and Acquisitions." Review of Financial Studies, 23 (2010), 601644.

Ferreira, M. A., and P. Matos. "The Colors of Investors' Money: The Role of Institutional Investors Around the World." Journal of Financial Economics, 88 (2008), 499-533.

Gillan, S. L., and L. T. Starks. "Corporate Governance Proposals and Shareholder Activism: The Role of Institutional Investors." Journal of Financial Economics, 57 (2000), 275-305.

Gillan, S. L., and L. T. Starks. "Corporate Governance, Corporate Ownership, and the Role of Institutional Investors: A Global Perspective." Journal of Applied Finance, 13 (2003), 422.

Ginarte, J. C., and W. G. Park. "Determinants of Patent Rights: A Cross-National Study." Research Policy, 26 (1997), 283-301.

Glucksberg, S. "The Influence of Strength of Drive on Functional Fixedness and Perceptual Recognition." Journal of Experimental Psychology, 63 (1962), 36-41

Gompers, P. A., and A. Metrick. "Institutional Investors and Equity Prices." Quarterly Journal of Economics, 116 (2001), 229-259. 
Griliches, Z.; A. Pakes; and B. H. Hall. "The Value of Patents as Indicator of Inventive Activity." Working Paper, NBER (1988).

Grinblatt, M., and M. Keloharju. "The Investment Behavior and Performance of Various Investor Types: A Study of Finland's Unique Data Set." Journal of Financial Economics, 55 (2000), 43-67.

Grossman, S. J., and O. D. Hart. "One Share-One Vote and the Market for Corporate Control." Journal of Financial Economics, 20 (1988), 175-202.

Guadalupe, M.; O. Kuzmina; and C. Thomas. "Innovation and Foreign Ownership." American Economic Review, 102 (2012), 3594-3627.

Hall, B. H.; A. B. Jaffe; and M. Trajtenberg. "The NBER Patent Citation Data File: Lessons, Insights and Methodological Tools." NBER Working Paper No. 8498 (2001).

Hall, B. H., and J. Lerner. “The Financing of R\&D and Innovation.” In Handbook of the Economics of Innovation, vol. 1, B. H. Hall and N. Rosenberg, eds. Amsterdam, The Netherlands: Elsevier (2010).

Hart, O. D. "The Market Mechanism as an Incentive Scheme." Bell Journal of Economics, 14 (1983), 366-382.

Hartzell, J. C., and L. T. Starks. "Institutional Investors and Executive Compensation." Journal of Finance, 58 (2003), 2351-2374.

He, J., and X. Tian. "The Dark Side of Analyst Coverage: The Case of Innovation." Journal of Financial Economics, 109 (2013), 856-878.

Holmstrom, B. "Agency Costs and Innovation." Journal of Economic Behavior and Organization, 12 (1989), 305-327. 
Hsu, P.-H.; X. Tian; and Y. Xu. "Financial Development and Innovation: Cross-Country Evidence." Journal of Financial Economics, 112 (2014), 116-135.

Jaffe, A. B.; M. Trajtenberg; and M. S. Fogarty. "Knowledge Spillovers and Patent Citations: Evidence from a Survey of Inventors." American Economic Review, 90 (2000), 215-218. Johnson, P.; V. Heimann; and K. O’Neill. "The 'Wonderland' of Virtual Teams." Journal of Workplace Learning, 13 (2001), 24-30.

Kahn, C., and A. Winton. "Ownership Structure, Speculation, and Shareholder Intervention." Journal of Finance, 53 (1998), 99-129.

Kaplan, S. N., and L. Zingales. "Do Investment-Cash Flow Sensitivities Provide Useful Measures of Financing Constraints?" Quarterly Journal of Economics, 112 (1997), 169215.

Kaufmann, D.; A. Kraay; and M. Mastruzzi. "The Worldwide Governance Indicators: Methodology and Analytical Issues." Hague Journal on the Rule of Law, 3 (2011), 220246.

Keller, W. "Geographic Localization of International Technology Diffusion." American Economic Review, 92 (2002), 120-142.

Koh, P.-S., and D. M. Reeb. "Missing R\&D." Journal of Accounting and Economics, 60 (2015), 73-94.

La Porta, R.; F. Lopez-de-Silanes; and A. Shleifer. "What Works in Securities Laws?" Journal of Finance, 61 (2006), 1-32.

Lau, S. T.; L. Ng; and B. Zhang. "The World Price of Home Bias." Journal of Financial Economics, 97 (2010), 191-217. 
Leuz, C.; K. V. Lins; and F. E. Warnock. "Do Foreigners Invest Less in Poorly Governed Firms?" Review of Financial Studies, 23 (2010), 3245-3285.

MacGarvie, M. "Do Firms Learn from International Trade?" Review of Economics and Statistics, 88 (2006), 46-60.

Manso, G. "Motivating Innovation." Journal of Finance, 66 (2011), 1823-1860.

Nanda, R., and M. Rhodes-Kropf. "Investment Cycles and Startup Innovation." Journal of Financial Economics, 110 (2013), 403-418.

Ng, L.; F. Wu; J. Yu; and B. Zhang. "Foreign Investor Heterogeneity and Stock Liquidity around the World." Review of Finance, 20 (2016), 1867-1910.

Park, W. G. "International Patent Protection: 1960-2005." Research Policy, 37 (2008), 761-766.

Pawar, K. S., and S. Sharifi. "Virtual Collocation of Design Teams: Coordinating for Speed." International Journal of Agile Management Systems, 2 (2000), 104-113.

Prasad, K., and K. B. Akhilesh. "Global Virtual Teams: What Impacts Their Design and Performance?" Team Performance Management: An International Journal, 8 (2002), $102-112$.

Ratcheva, V., and S. Vyakarnam. "The Challenges of Virtual Partnerships: Critical Success Factors in the Formation of Inter-Organisational Teams." AI \& SOCIETY, 15 (2001), 99116.

Seru, A. "Firm Boundaries Matter: Evidence from Conglomerates and R\&D Activity." Journal of Financial Economics, 111 (2014), 381-405.

Shleifer, A., and R. W. Vishny. "Large Shareholders and Corporate Control." Journal of Political Economy, 94 (1986), 461-488. 
Solow, R. M. "Technical Change and the Aggregate Production Function." Review of Economics and Statistics, 39 (1957), 312-320.

Stein, J. C. "Takeover Threats and Managerial Myopia." Journal of Political Economy, 96 (1988), 61-80.

Tian, X., and T. Y. Wang. "Tolerance for Failure and Corporate Innovation." Review of Financial Studies, 27 (2014), 211-255.

Trott, P. Innovation Management and New Product Development. Harlow, England: Financial Times/Prentice Hall (2008).

Voss, C. A. "Rethinking Paradigms of Service: Service in a Virtual Environment." International Journal of Operations and Production Management, 23 (2003), 88-104.

Wahal, S., and J. J. McConnell. "Do Institutional Investors Exacerbate Managerial Myopia?" Journal of Corporate Finance, 6 (2000), 307-329.

Walters, D., and J. Buchanan. "The New Economy, New Opportunities and New Structures." Management Decision, 39 (2001), 818-834.

Wright, D. T., and N. D. Burns. "New Organisation Structures for Global Business: An Empirical Study." International Journal of Operations and Production Management, 18 (1998), 896-923.

Xie, F.; B. Zhang; and W. Zhang. " Does Trust Create a Culture of Innovation?" Working Paper, University of New South Wales (2016). 


\section{APPENDIX A}

\section{Thomson Reuters's DWPI Classification System}

DWPI categorizes patents using a simple classification for all technologies. Patents are divided into 3 broad areas: Chemical, Engineering, and Electronic and Electrical Engineering. Each of these is then further classified into smaller subject areas called "Sections," which describe the technical area or areas covered by the patent. There are a total of 20 such sections, designated $\mathrm{A}-\mathrm{M}$ for Chemical, $\mathrm{P}-\mathrm{Q}$ for Engineering, and $\mathrm{S}-\mathrm{X}$ for Electronic and Electrical Engineering.

\section{Chemical}
A. Polymers and Plastics
B. Pharmaceuticals
C. Agricultural Chemicals
D. Food, Detergents, Water Treatment and Biotechnology
E. General Chemicals
F. Textiles and Paper-Making
G. Printing, Coating, Photographic
H. Petroleum

J. Chemical Engineering

K. Nucleonics, Explosives and Protection

L. Refractories, Ceramics, Cement and Electro(in)organics

M. Metallurgy 


\section{Engineering}

P1. Agriculture, Food, Tobacco

P2. Personal, Domestic

P3. Health, Amusement

P4. Separating, Mixing

P5. Shaping Metal

P6. Shaping Non-metal

P7. Pressing, Printing

P8. Optics, Photography, General

Q1. Vehicles in General

Q2. Special Vehicles

Q3. Conveying, Packaging, Storing

Q4. Buildings, Construction

Q5. Engines, Pumps

Q6. Engineering Elements

Q7. Lighting, Heating

Electronic and Electrical Engineering

S. Instrumentation, Measuring and Testing

T. Computing and Control

U. Semiconductors and Electronic Circuitry

V. Electronic Components

W. Communications 
X. Electric Power Engineering 
1. Innovation Variables (Source: Thomson Innovation)

$\ln ($ PATENT): Natural logarithm of 1 plus the total number of patents granted to each firm in each year scaled by the mean number of patent applications filed in a year for technology groups to which the patent belongs.

$\ln ($ CITEPAT): Natural logarithm of 1 plus the total number of citations made to each firm's patents in each year scaled by the mean citation count received by each patent in a year for technology groups to which the patent belongs.

\section{Institutional Ownership Variables (Source: FactSet Ownership)}

DIO: Domestic institutional ownership, defined as the sum of shares owned by all institutions domiciled in the same country as where the stock is listed, as a percentage of the firm's total number of shares outstanding, set to 0 if the stock is not held by any institution.

FIO: Foreign institutional ownership, defined as the sum of shares owned by all institutions domiciled in a country different from where the stock is listed, as a percentage of the firm's total number of shares outstanding, set to 0 if the stock is not held by any institution.

FIOINDEPENDENT: Independent foreign institutional ownership, defined as the sum of shares owned by all active foreign institutions (mutual funds and independent investment advisers), as a percentage of the firm's total number of shares outstanding. 
FIOGrey: Grey foreign institutional ownership, defined as the sum of shares owned by all passive foreign institutions (bank trusts, insurance companies, and other institutions), as a percentage of the firm's total number of shares outstanding.

FIOLONG_TERM: Long-term foreign institutional ownership, defined as the sum of shares owned by all foreign institutions that hold the stock for more than 1 year, as a percentage of the firm's total number of shares outstanding.

FIOSHORT_term: Short-term foreign institutional ownership, defined as the sum of shares owned by all foreign institutions that hold the stock for less than 1 year, as a percentage of the firm's total number of shares outstanding.

FIOHIGH_INNo: High-innovation foreign institutional ownership, defined as the sum of shares owned by all foreign institutions that come from high-innovation countries, as a percentage of the firm's total number of shares outstanding.

FIOLOW_INNo: Low-innovation foreign institutional ownership, defined as the sum of shares owned by all foreign institutions that come from low-innovation countries, as a percentage of the firm's total number of shares outstanding.

FIOHIGHINNO_HIGHGOv: High-innovation and high-governance foreign institutional ownership, defined as the sum of shares owned by all foreign institutions that come from highinnovation and high-governance countries, as a percentage of the firm's total number of shares outstanding.

FIOHIGHINNo_Lowgov: High-innovation and low-governance foreign institutional ownership, defined as the sum of shares owned by all foreign institutions that come from highinnovation and low-governance countries as a percentage of the firm's total number of shares outstanding. 
FIOLOWINNO_HIGHGOV: Low-innovation and high-governance foreign institutional ownership, defined as the sum of shares owned by all foreign institutions that come from lowinnovation and high-governance countries, as a percentage of the firm's total number of shares outstanding.

FIOLOWINNo_Lowgov: Low-innovation and low-governance foreign institutional ownership, defined as the sum of shares owned by all foreign institutions that come from lowinnovation and low-governance countries, as a percentage of the firm's total number of shares outstanding.

\section{Control Variables (Source: Worldscope)}

TA: Book value of total assets, measured at the end of the fiscal year in millions.

RD: Research and development expenditures scaled by total assets, measured at the end of the fiscal year, set to 0 if missing.

FSALE: The percentage of foreign sales in total sales.

INSIDE: Number of shares held by insiders as a proportion of the total number of shares outstanding.

$\ln ($ SALE): Natural logarithm of net sales.

$\ln (A G E)$ : Natural logarithm of the number of years since the firm has its listed price.

CAPEX: Capital expenditures divided by total assets, measured at the end of the fiscal year.

PPE: Net property, plant, and equipment scaled by total assets, measured at the end of the fiscal year.

LEV: Ratio of total debt to total assets, measured at the end of the fiscal year. 
ROA: Return on assets, defined as operating income before depreciation divided by total assets, measured at the end of the fiscal year.

KZ: The KZ index measured at the end of fiscal year, calculated as $-1.002 \times$ Cash flow [(Income before extraordinary items + Depreciation and Amortization)/Lagged net property, plant, and equipment] $+0.283 \times \mathrm{Q}$ [Market value of equity + book value of total assets - book value of equity - balance sheet deferred tax] $+3.139 \times$ Leverage[Total debt/Total assets] $-39.368 \times$ Dividends [(Preferred dividends + Common dividends)/Lagged net property, plant, and equipment] $-3.315 \times$ Cash holdings [(Cash and short-term investment)/(Lagged net property, plant, and equipment)].

TOBINS_Q: Growth opportunities, defined as market value of equity plus book value of assets minus book value of equity minus balance sheet deferred taxes, scaled by total assets, measured at the end of the fiscal year.

HHI: Herfindahl index of 4-digit Standard Industrial Classification (SIC) industry to which the firm belongs, measured at the end of the fiscal year.

$\mathrm{HHI}^{2}$ : Squared HHI.

4. Country-Level Innovativeness and Control Variables (Source: World Bank, WDI, and other sources)

PATENT_GDP: Total number of patent applications applied in a year by all residents of a country divided by GDP.

PATENT_POP: Total number of patent applications applied in a year by all residents of a country divided by total population. 
PATENT_FIRMS: Total number of patent applications applied in a year by all residents of a country divided by the number of listed firms.

PATENT_MCAP: Total number of patent applications applied in a year by all residents of a country divided by market capitalization.

P_INDEX: Patent protection index, developed by Ginarte and Park (1997), and updated by Park (2008). The index data are constructed for more than 100 countries, updated every 5 years since 1960 . The index takes values between 0 and 5 . Higher values indicate patent laws with stronger intellectual property rights. The index coding scheme aggregates information on i) membership in international treaties (Paris Convention, International Convention for the Protection of New Varieties of Plants, Patent Cooperation Treaty, Budapest Treaty, Agreement on Trade Related Aspects of Intellectual Property Rights), ii) enforcement mechanisms (preliminary injunctions, contributory infringement pleadings, burden of proof reversal), iii) restrictions on patent rights (working requirements, compulsory licensing, revocation of patents), iv) duration of protection, and v) extent of coverage (pharmaceuticals, chemicals, food, surgical products, microorganisms, utility models, software, plant and animal varieties).

RULE: The rule of law indicator of Kaufmann et al. (2011), which captures perceptions of the extent to which agents have confidence in and abide by the rules of society, and in particular, the quality of contract enforcement, property rights, the police, and the courts, as well as the likelihood of crime and violence.

GOODGOV: The government effectiveness indicator of Kaufmann et al. (2011), which captures perceptions of the quality of public services, the quality of the civil service 
and the degree of its independence from political pressures, the quality of policy formulation and implementation, and the credibility of the government's commitment to such policies.

EXPORT: The ratio of a country's export to its GDP.

IMPORT: The ratio of a country's import to its GDP.

EQUITY: The ratio of a country's stock market capitalization to its GDP.

CREDIT: The ratio of a country's bank credit to its GDP.

$\ln (\mathrm{GDP})$ : The natural logarithm of real GDP per capita. 


\section{TABLE 1}

\section{Summary of Firm Innovation and Institutional Ownership}

Table 1 reports the sample statistics for the 2000-2010 period. Panel A reports the means of innovation and institutional ownership sample data by country. Type of Markets reports if the economies are developed (DEV) or emerging (EMG) economies. No. of Firms is the number of firms in each sample country. No. of Firm-Years is the number of firm-year observations.

PATENT is the total number of patent applications filed by each firm in each year. CITEPAT is the total number of citations received by each firm's patents in each year. FIO and DIO are foreign institutional ownership and domestic institutional ownership, respectively. Panel B contains the summary statistics of firm- and country-level variables. Details of variable definitions are in Appendix B. 
TABLE 1 (continued)

Panel A. Firm Innovation and Institutional Ownership by Country

Innovation

Institutional Ownership

\begin{tabular}{|c|c|c|c|c|c|c|c|}
\hline Country & $\begin{array}{l}\text { Type of } \\
\text { Markets }\end{array}$ & $\begin{array}{l}\text { No. of } \\
\text { Firms } \\
\end{array}$ & $\begin{array}{c}\text { No. of } \\
\text { Firm-Years }\end{array}$ & PATENT & CITEPAT & FIO & DIO \\
\hline Australia & DEV & 120 & 730 & 0.886 & 2.697 & 4.220 & 1.347 \\
\hline Austria & DEV & 29 & 205 & 1.676 & 2.710 & 9.125 & 1.860 \\
\hline Belgium & DEV & 23 & 173 & 11.327 & 27.638 & 11.038 & 3.310 \\
\hline Brazil & EMG & 46 & 313 & 1.324 & 2.782 & 7.972 & 0.373 \\
\hline Canada & DEV & 246 & 1,579 & 1.954 & 4.272 & 9.589 & 13.996 \\
\hline Denmark & DEV & 19 & 231 & 6.547 & 31.353 & 7.932 & 10.826 \\
\hline Finland & DEV & 49 & 399 & 2.033 & 7.638 & 11.406 & 8.998 \\
\hline France & DEV & 215 & 1,466 & 9.194 & 13.053 & 6.903 & 4.539 \\
\hline Germany & DEV & 243 & 1,716 & 20.704 & 32.997 & 7.743 & 4.719 \\
\hline Greece & EMG & 14 & 66 & 0.242 & 0.098 & 1.834 & 0.570 \\
\hline Hong Kong & DEV & 13 & 101 & 0.426 & 0.391 & 7.399 & 1.205 \\
\hline India & EMG & 183 & 1,080 & 3.422 & 12.637 & 3.713 & 3.114 \\
\hline Israel & EMG & 62 & 343 & 1.708 & 4.123 & 18.997 & 1.029 \\
\hline Italy & DEV & 66 & 461 & 3.059 & 4.542 & 7.566 & 2.605 \\
\hline Japan & DEV & 1,309 & 11,209 & 25.451 & 40.599 & 2.747 & 2.369 \\
\hline Korea & EMG & 591 & 3,173 & 18.452 & 33.157 & 3.479 & 0.107 \\
\hline Netherlands & DEV & 20 & 160 & 14.721 & 21.250 & 18.668 & 4.631 \\
\hline New Zealand & DEV & 12 & 74 & 1.027 & 0.930 & 1.155 & 0.524 \\
\hline Norway & DEV & 47 & 267 & 2.404 & 4.506 & 8.722 & 10.223 \\
\hline Singapore & DEV & 36 & 291 & 1.218 & 1.594 & 5.460 & 1.083 \\
\hline South Africa & EMG & 16 & 120 & 0.267 & 0.193 & 8.429 & 4.197 \\
\hline Spain & DEV & 23 & 191 & 0.803 & 0.508 & 6.796 & 4.687 \\
\hline Sweden & DEV & 85 & 596 & 4.552 & 7.485 & 6.856 & 12.721 \\
\hline Switzerland & DEV & 40 & 323 & 12.251 & 29.860 & 9.891 & 6.039 \\
\hline Taiwan & EMG & 594 & 3,700 & 12.319 & 26.095 & 2.306 & 0.287 \\
\hline United Kingdom & DEV & 148 & 1,041 & 2.772 & 6.727 & 4.596 & 19.056 \\
\hline Developed & DEV & 2,743 & 21,213 & 16.841 & 27.514 & 5.052 & 5.036 \\
\hline Emerging & EMG & 1,506 & 8,795 & 12.379 & 24.755 & 3.834 & 0.656 \\
\hline All economies & ALL & 4,249 & 30,008 & 15.533 & 26.705 & 4.695 & 3.753 \\
\hline
\end{tabular}


TABLE 1 (continued)

Panel B. Summary Statistics

\begin{tabular}{|c|c|c|c|c|c|c|c|}
\hline Variables & No. of Firms & No. of Firm-Years & Mean & Std. Dev. & $\mathrm{P} 25$ & Median & $\mathrm{P} 75$ \\
\hline \multicolumn{8}{|l|}{ Innovation Variables } \\
\hline PATENT & 4,249 & 30,008 & 15.533 & 61.319 & 0.000 & 0.000 & 3.000 \\
\hline CITEPAT & 4,249 & 30,008 & 26.705 & 106.483 & 0.000 & 0.000 & 3.460 \\
\hline $\ln (\mathrm{PATENT})$ & 4,249 & 30,008 & 0.904 & 1.427 & 0.000 & 0.000 & 1.386 \\
\hline $\ln ($ CITEPAT $)$ & 4,249 & 30,008 & 0.957 & 1.670 & 0.000 & 0.000 & 1.495 \\
\hline \multicolumn{8}{|l|}{ Ownership Variables } \\
\hline FIO & 4,249 & 30,008 & 4.695 & 8.779 & 0.000 & 0.937 & 5.585 \\
\hline $\mathrm{FIO}_{\text {US }}$ & 4,249 & 30,008 & 2.380 & 6.245 & 0.000 & 0.269 & 1.949 \\
\hline $\mathrm{FIO}_{\text {NONUS }}$ & 4,249 & 30,008 & 2.316 & 4.418 & 0.000 & 0.247 & 2.840 \\
\hline FIOLONG_TERM & 4,249 & 30,008 & 4.561 & 8.583 & 0.000 & 0.835 & 5.388 \\
\hline FIOSHORT_TERM & 4,249 & 30,008 & 0.135 & 0.850 & 0.000 & 0.000 & 0.028 \\
\hline FIO INDEPENDENT $_{\text {IN }}$ & 4,249 & 30,008 & 4.443 & 8.456 & 0.000 & 0.852 & 5.203 \\
\hline FIO $_{\text {GREY }}$ & 4,249 & 30,008 & 0.252 & 0.657 & 0.000 & 0.000 & 0.153 \\
\hline FIOHIGH PATENT GDP $_{\text {HIT }}$ & 4,249 & 30,008 & 3.980 & 7.971 & 0.000 & 0.674 & 4.458 \\
\hline FIOLOW_PATENT GDP & 4,249 & 30,008 & 0.715 & 1.681 & 0.000 & 0.000 & 0.636 \\
\hline FIOHIGH_PATENT POP $_{\text {HIT }}$ & 4,249 & 30,008 & 4.403 & 8.442 & 0.000 & 0.826 & 5.128 \\
\hline FIOLLOW_PATENT POP & 4,249 & 30,008 & 0.292 & 0.952 & 0.000 & 0.000 & 0.080 \\
\hline FIOHIGH PATENT FIRMS & 4,249 & 30,008 & 4.166 & 8.225 & 0.000 & 0.711 & 4.711 \\
\hline FIOLLW_PATENT FIRMS & 4,249 & 30,008 & 0.530 & 1.514 & 0.000 & 0.000 & 0.300 \\
\hline FIO $_{\text {HIGH PATENT MCAP }}$ & 4,249 & 30,008 & 2.710 & 6.519 & 0.000 & 0.341 & 2.447 \\
\hline FIOLOW_PATENT MCAP & 4,249 & 30,008 & 1.985 & 3.881 & 0.000 & 0.182 & 2.418 \\
\hline DIO & 4,249 & 30,008 & 3.753 & 7.254 & 0.000 & 0.577 & 4.347 \\
\hline \multicolumn{8}{|l|}{ Control Variables } \\
\hline $\ln (\mathrm{TA})$ & 4,249 & 30,008 & 5.755 & 1.984 & 4.393 & 5.555 & 6.968 \\
\hline AGE & 4,249 & 30,008 & 14.528 & 10.634 & 6.000 & 12.000 & 20.000 \\
\hline $\ln (\mathrm{SALE})$ & 4,249 & 30,008 & 5.587 & 2.172 & 4.257 & 5.518 & 6.963 \\
\hline FSALE & 4,249 & 30,008 & 0.212 & 0.355 & 0.000 & 0.000 & 0.373 \\
\hline INSIDE & 4,249 & 30,008 & 0.273 & 0.260 & 0.000 & 0.244 & 0.467 \\
\hline HHI & 4,249 & 30,008 & 0.252 & 0.259 & 0.072 & 0.145 & 0.338 \\
\hline $\mathrm{HHI}^{2}$ & 4,249 & 30,008 & 0.130 & 0.246 & 0.005 & 0.021 & 0.114 \\
\hline $\mathrm{RD}$ & 4,249 & 30,008 & 0.032 & 0.067 & 0.000 & 0.008 & 0.033 \\
\hline CAPEX & 4,249 & 30,008 & 0.055 & 0.052 & 0.019 & 0.040 & 0.072 \\
\hline PPE & 4,249 & 30,008 & 0.286 & 0.181 & 0.142 & 0.271 & 0.405 \\
\hline LEV & 4,249 & 30,008 & 0.213 & 0.180 & 0.053 & 0.190 & 0.328 \\
\hline ROA & 4,249 & 30,008 & 0.074 & 0.119 & 0.044 & 0.089 & 0.137 \\
\hline TOBINS_Q & 4,249 & 30,008 & 1.570 & 1.392 & 0.922 & 1.151 & 1.636 \\
\hline $\mathrm{KZ}$ & 4,249 & 30,008 & -7.351 & 23.848 & -4.828 & -1.069 & 0.647 \\
\hline P INDEX & 4,249 & 30,008 & 4.370 & 0.451 & 4.170 & 4.670 & 4.670 \\
\hline GOODGOV & 4,249 & 30,008 & 1.338 & 0.470 & 1.120 & 1.420 & 1.620 \\
\hline RULE & 4,249 & 30,008 & 1.227 & 0.438 & 0.970 & 1.290 & 1.550 \\
\hline EXPORT & 4,249 & 30,008 & 0.324 & 0.265 & 0.143 & 0.263 & 0.421 \\
\hline IMPORT & 4,249 & 30,008 & 0.300 & 0.238 & 0.129 & 0.278 & 0.371 \\
\hline EQUITY & 4,249 & 30,008 & 0.896 & 0.446 & 0.613 & 0.790 & 1.085 \\
\hline CREDIT & 4,249 & 30,008 & 1.372 & 1.368 & 0.000 & 1.255 & 3.020 \\
\hline $\ln (\mathrm{GDP})$ & 4,249 & 30,008 & 10.207 & 0.502 & 10.248 & 10.320 & 10.376 \\
\hline
\end{tabular}




\section{TABLE 2}

\section{Baseline Regressions}

Table 2 reports the regressions of firm innovation on institutional ownership. Columns 1-2 (3-4) show the pooled OLS (firm-fixed effects) regression results. The dependent variable is shown as column heading in columns $1-4$. The main independent variable is foreign institutional ownership (FIO). All explanatory variables are lagged by 1 year. Variable definitions are in Appendix B. Standard errors are clustered at the firm level and reported below in parentheses. *, $* *$, and $* * *$ indicate significance at the $10 \%, 5 \%$, and $1 \%$ levels, respectively. 
TABLE 2 (continued)

$\ln ($ PATENT $) \quad \ln ($ CITEPAT $) \quad \ln ($ PATENT $) \quad \ln ($ CITEPAT $)$

\begin{tabular}{|c|c|c|c|c|}
\hline Variables & 1 & 2 & 3 & 4 \\
\hline FIO & $\begin{array}{c}0.010 * * * \\
(0.003)\end{array}$ & $\begin{array}{c}0.014 * * * \\
(0.004)\end{array}$ & $\begin{array}{c}0.008 * * * \\
(0.003)\end{array}$ & $\begin{array}{c}0.011 * * * \\
(0.004)\end{array}$ \\
\hline DIO & $\begin{array}{c}-0.010^{* * *} \\
(0.002)\end{array}$ & $\begin{array}{c}-0.012 * * * \\
(0.003)\end{array}$ & $\begin{array}{c}-0.001 \\
(0.001)\end{array}$ & $\begin{array}{l}-0.001 \\
(0.002)\end{array}$ \\
\hline INSIDE & $\begin{array}{l}-0.072 \\
(0.063)\end{array}$ & $\begin{array}{l}-0.054 \\
(0.070)\end{array}$ & $\begin{array}{l}0.062^{*} \\
(0.032)\end{array}$ & $\begin{array}{l}0.084^{*} \\
(0.044)\end{array}$ \\
\hline $\ln (\mathrm{AGE})$ & $\begin{array}{c}0.062 * * \\
(0.029)\end{array}$ & $\begin{array}{l}0.062^{*} \\
(0.032)\end{array}$ & $\begin{array}{c}0.086 * * \\
(0.037)\end{array}$ & $\begin{array}{c}0.118^{* *} \\
(0.049)\end{array}$ \\
\hline HHI & $\begin{array}{c}0.396 \\
(0.292)\end{array}$ & $\begin{array}{c}0.400 \\
(0.326)\end{array}$ & $\begin{array}{l}-0.170 \\
(0.274)\end{array}$ & $\begin{array}{c}0.152 \\
(0.347)\end{array}$ \\
\hline $\mathrm{HHI}^{2}$ & $\begin{array}{l}-0.277 \\
(0.277)\end{array}$ & $\begin{array}{c}-0.280 \\
(0.307)\end{array}$ & $\begin{array}{c}0.152 \\
(0.241)\end{array}$ & $\begin{array}{c}0.050 \\
(0.290)\end{array}$ \\
\hline $\mathrm{RD}$ & $\begin{array}{c}2.267 * * * \\
(0.238)\end{array}$ & $\begin{array}{c}2.637 * * * \\
(0.288)\end{array}$ & $\begin{array}{c}0.054 \\
(0.132)\end{array}$ & $\begin{array}{c}-0.232 \\
(0.215)\end{array}$ \\
\hline CAPEX & $\begin{array}{c}2.313 * * * \\
(0.269)\end{array}$ & $\begin{array}{c}2.913 * * * \\
(0.308)\end{array}$ & $\begin{array}{c}0.378^{* * *} \\
(0.134)\end{array}$ & $\begin{array}{c}0.519 * * * \\
(0.184)\end{array}$ \\
\hline PPE & $\begin{array}{c}-0.232 * * \\
(0.116)\end{array}$ & $\begin{array}{l}-0.192 \\
(0.129)\end{array}$ & $\begin{array}{l}-0.082 \\
(0.086)\end{array}$ & $\begin{array}{l}-0.095 \\
(0.114)\end{array}$ \\
\hline LEV & $\begin{array}{c}-0.365^{* * *} * \\
(0.097)\end{array}$ & $\begin{array}{c}-0.453^{* * *} * \\
(0.104)\end{array}$ & $\begin{array}{c}-0.132 * * \\
(0.057)\end{array}$ & $\begin{array}{c}-0.185^{*} * * \\
(0.070)\end{array}$ \\
\hline ROA & $\begin{array}{c}-0.616^{* * *} \\
(0.144)\end{array}$ & $\begin{array}{c}-0.850 * * * \\
(0.165)\end{array}$ & $\begin{array}{l}-0.037 \\
(0.079)\end{array}$ & $\begin{array}{l}-0.169 \\
(0.108)\end{array}$ \\
\hline FSALE & $\begin{array}{c}0.138 * * \\
(0.067)\end{array}$ & $\begin{array}{l}0.169^{*} \\
(0.088)\end{array}$ & $\begin{array}{c}0.000 \\
(0.020)\end{array}$ & $\begin{array}{l}-0.009 \\
(0.018)\end{array}$ \\
\hline $\ln (\mathrm{SALE})$ & $\begin{array}{c}0.276^{* * * *} \\
(0.016)\end{array}$ & $\begin{array}{c}0.317 * * * \\
(0.018)\end{array}$ & $\begin{array}{c}0.110^{* * *} \\
(0.015)\end{array}$ & $\begin{array}{c}0.115^{* * * *} \\
(0.020)\end{array}$ \\
\hline TOBINS_Q & $\begin{array}{c}0.071 * * * \\
(0.011)\end{array}$ & $\begin{array}{c}0.099 * * * \\
(0.014)\end{array}$ & $\begin{array}{c}0.005 \\
(0.005)\end{array}$ & $\begin{array}{c}0.001 \\
(0.008)\end{array}$ \\
\hline KZ & $\begin{array}{c}-0.002 * * * \\
(0.001)\end{array}$ & $\begin{array}{c}-0.003 * * * \\
(0.001)\end{array}$ & $\begin{array}{c}-0.001 * * * \\
(0.000)\end{array}$ & $\begin{array}{c}-0.001 * * * \\
(0.000)\end{array}$ \\
\hline $\mathrm{P}$ INDEX & $\begin{array}{c}0.115^{* *} \\
(0.047)\end{array}$ & $\begin{array}{c}0.186^{* * *} * \\
(0.064)\end{array}$ & $\begin{array}{c}0.116^{* * * *} \\
(0.045)\end{array}$ & $\begin{array}{c}0.150 * * \\
(0.062)\end{array}$ \\
\hline RULE & $\begin{array}{c}0.098 \\
(0.080)\end{array}$ & $\begin{array}{c}0.051 \\
(0.100)\end{array}$ & $\begin{array}{l}-0.033 \\
(0.071)\end{array}$ & $\begin{array}{l}-0.081 \\
(0.093)\end{array}$ \\
\hline GOODGOV & $\begin{array}{c}0.128^{* *} \\
(0.053)\end{array}$ & $\begin{array}{l}0.116^{*} \\
(0.066)\end{array}$ & $\begin{array}{c}0.131 * * * \\
(0.049)\end{array}$ & $\begin{array}{c}0.131^{* *} \\
(0.062)\end{array}$ \\
\hline EXPORT & $\begin{array}{c}0.283 \\
(0.409)\end{array}$ & $\begin{array}{c}0.096 \\
(0.498)\end{array}$ & $\begin{array}{l}-0.027 \\
(0.383)\end{array}$ & $\begin{array}{l}-0.117 \\
(0.465)\end{array}$ \\
\hline IMPORT & $\begin{array}{c}0.886^{* *} \\
(0.440)\end{array}$ & $\begin{array}{c}0.555 \\
(0.549)\end{array}$ & $\begin{array}{l}0.793^{*} \\
(0.406)\end{array}$ & $\begin{array}{c}0.483 \\
(0.517)\end{array}$ \\
\hline EQUITY & $\begin{array}{c}0.078^{* *} \\
(0.031)\end{array}$ & $\begin{array}{c}0.012 \\
(0.039)\end{array}$ & $\begin{array}{c}0.089 * * * \\
(0.028)\end{array}$ & $\begin{array}{l}0.067^{*} \\
(0.036)\end{array}$ \\
\hline CREDIT & $\begin{array}{l}-0.017 \\
(0.014)\end{array}$ & $\begin{array}{c}-0.048 * * * \\
(0.017)\end{array}$ & $\begin{array}{c}0.014 \\
(0.011)\end{array}$ & $\begin{array}{l}-0.005 \\
(0.015)\end{array}$ \\
\hline $\ln (\mathrm{GDP})$ & $\begin{array}{c}0.233 * * * \\
(0.073)\end{array}$ & $\begin{array}{l}0.155^{*} \\
(0.090)\end{array}$ & $\begin{array}{c}0.151 * * \\
(0.066)\end{array}$ & $\begin{array}{c}0.105 \\
(0.086)\end{array}$ \\
\hline Year fixed effects & Yes & Yes & Yes & Yes \\
\hline Firm fixed effects & No & No & Yes & Yes \\
\hline Industry fixed effects & Yes & Yes & No & No \\
\hline Country fixed effects & Yes & Yes & No & No \\
\hline Adj. $R^{2}$ & 0.246 & 0.238 & 0.851 & 0.766 \\
\hline No. of obs. & 30,008 & 30,008 & 30,008 & 30,008 \\
\hline
\end{tabular}




\section{TABLE 3}

\section{Difference-in-Differences Analysis}

Table 3 reports the diagnostics and results of the difference-in-differences (DID) tests on how a plausibly exogenous shock to foreign institutional ownership due to the passage of the JGTRRA in 2003 affects firm innovation. Treatment firms must pay dividends in the pretax cut year (2002) and be domiciled in treaty countries. Control firms must be domiciled in non-treaty countries and pay dividends in the pretax cut year (2002). Each control firm is then matched to 5 treatment firms using the nearest neighbor propensity score matching procedure, on a vector of firm- and country-level characteristics as in the baseline regression, and innovation growth variables (GROWTHPATENT and GROWTHCITATION) over 3 years before the tax cut. Panel A reports the univariate comparison between innovation growth variables of treatment firms and those of control firms, and their corresponding $t$-statistics. Panel B reports the univariate DID estimators with standard errors displayed below in parentheses. Panel C reports the multivariate DID test results with standard errors adjusted for firm-level clustering displayed below in parentheses. $*, * *$, and $* * *$ indicate significance at the $10 \%, 5 \%$, and $1 \%$ levels, respectively.

Panel A. Differences in Innovation Growth Variables

\begin{tabular}{lcccc}
\multicolumn{1}{c}{ Variables } & Treatment & Control & Differences & $t$-Statistics \\
\hline & & & & \\
GROWTH & & & \\
GROTENT & 0.468 & 0.391 & 0.077 & 1.56 \\
GROWHATION & 0.363 & 0.301 & 0.062 & 1.15
\end{tabular}

Panel B. Difference-in-Differences Test

\begin{tabular}{|c|c|c|c|c|}
\hline & $\begin{array}{c}\text { Treatment } \\
\text { After - Before }\end{array}$ & $\begin{array}{c}\text { Control } \\
\text { After - Before }\end{array}$ & $\begin{array}{l}\text { Treatment - Control } \\
\text { DID Estimator }\end{array}$ & $t$-Statistics for DID \\
\hline Variables & 1 & 2 & 3 & 4 \\
\hline $\ln ($ PATENT) & $\begin{array}{c}0.178 \\
(0.047)\end{array}$ & $\begin{array}{c}0.079 \\
(0.035)\end{array}$ & $0.099 * *$ & 2.215 \\
\hline $\ln ($ CITEPAT) & $\begin{array}{c}0.205 \\
(0.054)\end{array}$ & $\begin{array}{c}0.082 \\
(0.033)\end{array}$ & $0.123 * * *$ & 2.849 \\
\hline
\end{tabular}


TABLE 3 (continued)

Panel C. Multivariate Difference-in-Differences Test

\begin{tabular}{|c|c|c|c|c|c|c|}
\hline \multirow[b]{2}{*}{ Variables } & \multicolumn{2}{|c|}{$\mathrm{FIO}_{\text {US }}$} & \multicolumn{2}{|c|}{$\ln (\mathrm{PATENT})$} & \multicolumn{2}{|c|}{$\ln ($ CITEPAT $)$} \\
\hline & 1 & 2 & 3 & 4 & 5 & 6 \\
\hline TREAT $\times$ POST & $\begin{array}{c}1.501 * * * \\
(0.076)\end{array}$ & $\begin{array}{c}1.089 * * * \\
(0.079)\end{array}$ & $\begin{array}{c}0.109 * * * \\
(0.020)\end{array}$ & $\begin{array}{c}0.091 * * * \\
(0.022)\end{array}$ & $\begin{array}{c}0.121 * * * \\
(0.029)\end{array}$ & $\begin{array}{c}0.115 * * * \\
(0.033)\end{array}$ \\
\hline $\mathrm{FIO}_{\text {NONUS }}$ & & $\begin{array}{c}0.091 * * * \\
(0.022)\end{array}$ & & $\begin{array}{c}0.017 * * \\
(0.007)\end{array}$ & & $\begin{array}{l}0.021 * \\
(0.011)\end{array}$ \\
\hline DIO & & $\begin{array}{c}0.018 * * \\
(0.009)\end{array}$ & & $\begin{array}{l}-0.002 \\
(0.005)\end{array}$ & & $\begin{array}{c}-0.009 \\
(0.008)\end{array}$ \\
\hline INSIDE & & $\begin{array}{c}0.194 \\
(0.181)\end{array}$ & & $\begin{array}{c}0.094 \\
(0.092)\end{array}$ & & $\begin{array}{c}0.077 \\
(0.123)\end{array}$ \\
\hline $\ln (\mathrm{AGE})$ & & $\begin{array}{c}-0.058 \\
(0.152)\end{array}$ & & $\begin{array}{c}0.338 * * * \\
(0.071)\end{array}$ & & $\begin{array}{c}0.243 * * \\
(0.108)\end{array}$ \\
\hline HHI & & $\begin{array}{c}1.250 \\
(1.286)\end{array}$ & & $\begin{array}{l}1.013^{*} \\
(0.586)\end{array}$ & & $\begin{array}{c}0.753 \\
(0.883)\end{array}$ \\
\hline $\mathrm{HHI}^{2}$ & & $\begin{array}{l}-1.229 \\
(1.240)\end{array}$ & & $\begin{array}{l}-0.751 \\
(0.512)\end{array}$ & & $\begin{array}{c}-0.591 \\
(0.837)\end{array}$ \\
\hline $\mathrm{RD}$ & & $\begin{array}{l}-0.648 \\
(1.527)\end{array}$ & & $\begin{array}{c}0.621 \\
(0.851)\end{array}$ & & $\begin{array}{c}0.002 \\
(1.164)\end{array}$ \\
\hline CAPEX & & $\begin{array}{c}0.487 \\
(0.673)\end{array}$ & & $\begin{array}{c}0.261 \\
(0.303)\end{array}$ & & $\begin{array}{c}0.135 \\
(0.483)\end{array}$ \\
\hline PPE & & $\begin{array}{l}0.915^{*} \\
(0.469)\end{array}$ & & $\begin{array}{c}0.280 \\
(0.195)\end{array}$ & & $\begin{array}{c}0.090 \\
(0.301)\end{array}$ \\
\hline LEV & & $\begin{array}{c}0.077 \\
(0.362)\end{array}$ & & $\begin{array}{c}-0.240 \\
(0.174)\end{array}$ & & $\begin{array}{l}-0.277 \\
(0.254)\end{array}$ \\
\hline $\mathrm{ROA}$ & & $\begin{array}{l}-0.695 \\
(0.578)\end{array}$ & & $\begin{array}{c}-0.767 * * * \\
(0.292)\end{array}$ & & $\begin{array}{c}-0.504 \\
(0.393)\end{array}$ \\
\hline FSALE & & $\begin{array}{l}-0.161 \\
(0.247)\end{array}$ & & $\begin{array}{c}0.098 \\
(0.101)\end{array}$ & & $\begin{array}{c}-0.139 \\
(0.166)\end{array}$ \\
\hline $\ln (\mathrm{SALE})$ & & $\begin{array}{c}0.578 * * * \\
(0.113)\end{array}$ & & $\begin{array}{c}0.111 * * * \\
(0.037)\end{array}$ & & $\begin{array}{c}0.137 * * * \\
(0.042)\end{array}$ \\
\hline TOBINS_Q & & $\begin{array}{c}0.055 \\
(0.038)\end{array}$ & & $\begin{array}{c}-0.040 * * \\
(0.018)\end{array}$ & & $\begin{array}{c}-0.066^{* *} * \\
(0.029)\end{array}$ \\
\hline $\mathrm{KZ}$ & & $\begin{array}{c}0.003 \\
(0.002)\end{array}$ & & $\begin{array}{l}-0.002 * \\
(0.001)\end{array}$ & & $\begin{array}{c}-0.002^{*} \\
(0.001)\end{array}$ \\
\hline P_INDEX & & $\begin{array}{c}0.049 \\
(0.187)\end{array}$ & & $\begin{array}{c}0.246 * * * \\
(0.071)\end{array}$ & & $\begin{array}{c}0.386 * * * \\
(0.136)\end{array}$ \\
\hline RULE & & $\begin{array}{l}-0.392 \\
(0.323)\end{array}$ & & $\begin{array}{l}-0.212 \\
(0.137)\end{array}$ & & $\begin{array}{c}0.031 \\
(0.197)\end{array}$ \\
\hline GOODGOV & & $\begin{array}{c}0.884 * * * \\
(0.267)\end{array}$ & & $\begin{array}{c}0.144 \\
(0.107)\end{array}$ & & $\begin{array}{c}0.159 \\
(0.165)\end{array}$ \\
\hline EXPORT & & $\begin{array}{c}6.209 * * * \\
(2.032)\end{array}$ & & $\begin{array}{c}0.143 \\
(0.738)\end{array}$ & & $\begin{array}{c}-2.502 * * \\
(1.072)\end{array}$ \\
\hline IMPORT & & $\begin{array}{c}-6.101 * * * \\
(2.213)\end{array}$ & & $\begin{array}{c}-0.454 \\
(0.916)\end{array}$ & & $\begin{array}{c}3.039 * * \\
(1.355)\end{array}$ \\
\hline EQUITY & & $\begin{array}{c}0.162 \\
(0.218)\end{array}$ & & $\begin{array}{c}0.194 * * \\
(0.086)\end{array}$ & & $\begin{array}{c}0.350 * * * \\
(0.136)\end{array}$ \\
\hline CREDIT & & $\begin{array}{c}0.114 \\
(0.071)\end{array}$ & & $\begin{array}{l}-0.016 \\
(0.032)\end{array}$ & & $\begin{array}{c}-0.024 \\
(0.045)\end{array}$ \\
\hline $\ln (\mathrm{GDP})$ & & $\begin{array}{c}0.570 \\
(0.360)\end{array}$ & & $\begin{array}{l}0.293^{*} \\
(0.153)\end{array}$ & & $\begin{array}{c}0.002 \\
(0.246)\end{array}$ \\
\hline Year fixed effects & Yes & Yes & Yes & Yes & Yes & Yes \\
\hline Firm fixed effects & Yes & Yes & Yes & Yes & Yes & Yes \\
\hline Adj. $R^{2}$ & 0.821 & 0.839 & 0.844 & 0.867 & 0.800 & 0.826 \\
\hline No. of obs. & 4,788 & 4,788 & 4,788 & 4,788 & 4,788 & 4,788 \\
\hline
\end{tabular}




\section{TABLE 4}

\section{Instrumental Variable Approach}

Table 4 presents the 2-stage least squares (2SLS) regressions of firm innovation on foreign institutional ownership. The instrumental variable for foreign institutional ownership (MSCI) is the time-varying membership of the MSCI All Country World Index. All explanatory variables are lagged by 1 year and defined as in Appendix B. Standard errors are clustered at the firm level and reported below in parentheses. $*, * *$, and $* * *$ indicate significance at the $10 \%, 5 \%$, and $1 \%$ levels, respectively. 
TABLE 4 (continued)

$\frac{1 \mathrm{SLS}}{\mathrm{FIO}} \frac{2 \mathrm{SLS}}{\ln (\text { PATENT }) \ln (\mathrm{CITEPAT})} \frac{1 \mathrm{SLS}}{\mathrm{FIO}} \frac{2 \mathrm{SLS}}{\ln \text { (PATENT) } \ln (\mathrm{CITEPAT})}$

\begin{tabular}{|c|c|c|c|c|c|c|}
\hline Variables & 1 & 2 & 3 & 4 & 5 & 6 \\
\hline MSCI & $\begin{array}{c}4.331 * * * \\
(0.314)\end{array}$ & & & $\begin{array}{c}2.141 * * * \\
(0.130)\end{array}$ & & \\
\hline FIO $_{\text {PREDICTED }}$ & & $\begin{array}{c}0.076 * * * \\
(0.022)\end{array}$ & $\begin{array}{c}0.084 * * * \\
(0.024)\end{array}$ & & $\begin{array}{c}0.037 * * * \\
(0.009)\end{array}$ & $\begin{array}{c}0.046^{* * *} \\
(0.013)\end{array}$ \\
\hline DIO & $\begin{array}{c}0.107^{* * *} \\
(0.023)\end{array}$ & $\begin{array}{c}-0.019 * * * \\
(0.005)\end{array}$ & $\begin{array}{c}-0.025^{* * *} \\
(0.005)\end{array}$ & $\begin{array}{c}0.016^{* * *} \\
(0.005)\end{array}$ & $\begin{array}{l}-0.001 \\
(0.001)\end{array}$ & $\begin{array}{l}-0.001 \\
(0.002)\end{array}$ \\
\hline INSIDE & $\begin{array}{c}-4.275 * * * \\
(0.354)\end{array}$ & $\begin{array}{c}0.570 * * * \\
(0.127)\end{array}$ & $\begin{array}{c}0.667 * * * \\
(0.142)\end{array}$ & $\begin{array}{c}-2.125^{* * *} \\
(0.188)\end{array}$ & $\begin{array}{c}0.096^{* *} \\
(0.047)\end{array}$ & $\begin{array}{c}0.159 * * * \\
(0.057)\end{array}$ \\
\hline $\ln (\mathrm{AGE})$ & $\begin{array}{c}-0.452 * * * \\
(0.149)\end{array}$ & $\begin{array}{c}0.097 * * * \\
(0.036)\end{array}$ & $\begin{array}{c}0.102 * * \\
(0.040)\end{array}$ & $\begin{array}{c}-0.709 * * * \\
(0.165)\end{array}$ & $\begin{array}{c}0.110^{* * *} \\
(0.023)\end{array}$ & $\begin{array}{c}0.135^{* * *} \\
(0.033)\end{array}$ \\
\hline HHI & $\begin{array}{c}0.099 \\
(1.438)\end{array}$ & $\begin{array}{c}0.270 \\
(0.350)\end{array}$ & $\begin{array}{c}0.258 \\
(0.391)\end{array}$ & $\begin{array}{l}2.112^{*} \\
(1.157)\end{array}$ & $\begin{array}{c}-0.258 \\
(0.162)\end{array}$ & $\begin{array}{c}0.084 \\
(0.229)\end{array}$ \\
\hline $\mathrm{HHI}^{2}$ & $\begin{array}{c}0.198 \\
(1.479)\end{array}$ & $\begin{array}{c}-0.257 \\
(0.334)\end{array}$ & $\begin{array}{l}-0.257 \\
(0.372)\end{array}$ & $\begin{array}{l}-1.588 \\
(1.023)\end{array}$ & $\begin{array}{c}0.213 \\
(0.143)\end{array}$ & $\begin{array}{c}0.097 \\
(0.202)\end{array}$ \\
\hline $\mathrm{RD}$ & $\begin{array}{l}3.233^{*} \\
(1.927)\end{array}$ & $\begin{array}{c}1.819 * * * \\
(0.353)\end{array}$ & $\begin{array}{c}2.137 * * * \\
(0.403)\end{array}$ & $\begin{array}{c}-2.139 * * \\
(0.873)\end{array}$ & $\begin{array}{c}0.149 \\
(0.123)\end{array}$ & $\begin{array}{l}-0.160 \\
(0.174)\end{array}$ \\
\hline CAPEX & $\begin{array}{c}3.861 * * * \\
(1.408)\end{array}$ & $\begin{array}{c}1.708 * * * \\
(0.345)\end{array}$ & $\begin{array}{c}2.238^{* * * *} \\
(0.390)\end{array}$ & $\begin{array}{c}2.414 * * * \\
(0.739)\end{array}$ & $\begin{array}{c}0.274 * * \\
(0.105)\end{array}$ & $\begin{array}{c}0.443 * * * \\
(0.149)\end{array}$ \\
\hline PPE & $\begin{array}{c}0.781 \\
(0.710)\end{array}$ & $\begin{array}{c}-0.332 * * \\
(0.151)\end{array}$ & $\begin{array}{c}-0.304^{*} \\
(0.168)\end{array}$ & $\begin{array}{c}0.353 \\
(0.454)\end{array}$ & $\begin{array}{l}-0.090 \\
(0.063)\end{array}$ & $\begin{array}{l}-0.101 \\
(0.089)\end{array}$ \\
\hline LEV & $\begin{array}{c}-4.076^{* * *} \\
(0.495)\end{array}$ & $\begin{array}{c}-0.191 \\
(0.150)\end{array}$ & $\begin{array}{l}-0.170 \\
(0.164)\end{array}$ & $\begin{array}{c}-2.264 * * * \\
(0.185)\end{array}$ & $\begin{array}{l}-0.033 \\
(0.047)\end{array}$ & $\begin{array}{l}-0.110^{*} \\
(0.067)\end{array}$ \\
\hline ROA & $\begin{array}{c}0.438 \\
(0.904)\end{array}$ & $\begin{array}{c}-0.467 * * \\
(0.181)\end{array}$ & $\begin{array}{c}-0.683 * * * \\
(0.206)\end{array}$ & $\begin{array}{c}-1.180 * * \\
(0.475)\end{array}$ & $\begin{array}{c}0.016 \\
(0.067)\end{array}$ & $\begin{array}{l}-0.129 \\
(0.095)\end{array}$ \\
\hline FSALE & $\begin{array}{c}2.674 * * \\
(1.047)\end{array}$ & $\begin{array}{c}-0.223^{*} \\
(0.118)\end{array}$ & $\begin{array}{c}-0.236^{*} \\
(0.121)\end{array}$ & $\begin{array}{c}0.193^{*} \\
(0.115)\end{array}$ & $\begin{array}{l}-0.009 \\
(0.016)\end{array}$ & $\begin{array}{c}-0.016 \\
(0.023)\end{array}$ \\
\hline $\ln (\mathrm{SALE})$ & $\begin{array}{c}1.402 * * * \\
(0.092)\end{array}$ & $\begin{array}{c}0.037 * * * \\
(0.012)\end{array}$ & $\begin{array}{c}0.049 * * * \\
(0.016)\end{array}$ & $\begin{array}{c}1.318^{* * *} \\
(0.044)\end{array}$ & $\begin{array}{c}0.050^{* * *} \\
(0.016)\end{array}$ & $\begin{array}{c}0.070^{* * *} \\
(0.023)\end{array}$ \\
\hline TOBINS_Q & $\begin{array}{c}0.576^{* * *} \\
(0.078)\end{array}$ & $\begin{array}{c}0.022 \\
(0.021)\end{array}$ & $\begin{array}{c}0.005 \\
(0.024)\end{array}$ & $\begin{array}{c}0.211^{* * *} \\
(0.031)\end{array}$ & $\begin{array}{c}0.007 \\
(0.005)\end{array}$ & $\begin{array}{c}0.009 \\
(0.007)\end{array}$ \\
\hline KZ & $\begin{array}{c}-0.009 * * * \\
(0.004)\end{array}$ & $\begin{array}{c}-0.002 * * \\
(0.001)\end{array}$ & $\begin{array}{l}-0.002^{*} \\
(0.001)\end{array}$ & $\begin{array}{c}-0.005^{* * *} \\
(0.001)\end{array}$ & $\begin{array}{c}-0.001 * * \\
(0.000)\end{array}$ & $\begin{array}{c}-0.001 * * * \\
(0.000)\end{array}$ \\
\hline P_INDEX & $\begin{array}{c}0.378 \\
(0.329)\end{array}$ & $\begin{array}{c}0.160^{* *} \\
(0.063)\end{array}$ & $\begin{array}{c}0.237 * * * \\
(0.079)\end{array}$ & $\begin{array}{c}0.291^{* *} \\
(0.136)\end{array}$ & $\begin{array}{c}0.121^{* * *} \\
(0.031)\end{array}$ & $\begin{array}{c}0.156^{* * *} \\
(0.044)\end{array}$ \\
\hline RULE & $\begin{array}{c}0.492 \\
(0.660)\end{array}$ & $\begin{array}{c}0.026 \\
(0.118)\end{array}$ & $\begin{array}{c}0.029 \\
(0.139)\end{array}$ & $\begin{array}{l}-0.083 \\
(0.241)\end{array}$ & $\begin{array}{l}-0.015 \\
(0.055)\end{array}$ & $\begin{array}{l}-0.068 \\
(0.078)\end{array}$ \\
\hline GOODGOV & $\begin{array}{c}-2.315 * * * \\
(0.471)\end{array}$ & $\begin{array}{c}0.431 * * * \\
(0.096)\end{array}$ & $\begin{array}{c}0.456 * * * \\
(0.111)\end{array}$ & $\begin{array}{c}-0.306^{*} \\
(0.161)\end{array}$ & $\begin{array}{c}0.194 * * * \\
(0.039)\end{array}$ & $\begin{array}{c}0.182 * * * \\
(0.055)\end{array}$ \\
\hline EXPORT & $\begin{array}{l}7.363^{*} \\
(4.132)\end{array}$ & $\begin{array}{c}-0.732 \\
(0.710)\end{array}$ & $\begin{array}{l}-1.038 \\
(0.820)\end{array}$ & $\begin{array}{c}5.806^{* * * *} \\
(1.244)\end{array}$ & $\begin{array}{c}-0.504 \\
(0.391)\end{array}$ & $\begin{array}{l}-0.489 \\
(0.425)\end{array}$ \\
\hline IMPORT & $\begin{array}{c}-8.516^{* *} \\
(4.206)\end{array}$ & $\begin{array}{c}2.047 * * * \\
(0.732)\end{array}$ & $\begin{array}{l}1.854^{* *} \\
(0.853)\end{array}$ & $\begin{array}{c}-6.556^{* * *} \\
(1.403)\end{array}$ & $\begin{array}{c}1.419 * * * \\
(0.345)\end{array}$ & $\begin{array}{c}0.972 * * \\
(0.488)\end{array}$ \\
\hline EQUITY & $\begin{array}{c}-0.281 \\
(0.370)\end{array}$ & $\begin{array}{c}0.115^{* *} \\
(0.058)\end{array}$ & $\begin{array}{c}0.053 \\
(0.068)\end{array}$ & $\begin{array}{l}-0.138 \\
(0.172)\end{array}$ & $\begin{array}{c}0.098^{* * *} \\
(0.024)\end{array}$ & $\begin{array}{c}0.074 * * \\
(0.034)\end{array}$ \\
\hline
\end{tabular}




\begin{tabular}{lcccccc} 
CREDIT & $-0.308^{* * *}$ & 0.019 & -0.007 & $-0.390^{* * *}$ & $0.031^{* * *}$ & 0.008 \\
& $(0.098)$ & $(0.020)$ & $(0.023)$ & $(0.074)$ & $(0.011)$ & $(0.015)$ \\
$\ln (\mathrm{GDP})$ & $1.091^{* *}$ & 0.128 & 0.036 & $0.892^{* *}$ & $0.105^{* *}$ & $0.117^{*}$ \\
& $(0.530)$ & $(0.101)$ & $(0.122)$ & $(0.305)$ & $(0.043)$ & $(0.060)$ \\
Year fixed effects & Yes & Yes & Yes & Yes & Yes & Yes \\
Firm fixed effects & No & No & No & Yes & Yes & Yes \\
Industry fixed effects & Yes & Yes & Yes & No & No & No \\
Country fixed effects & Yes & Yes & Yes & No & No & No \\
$F$-test $(p$-value) & $<0.001$ & & & $<0.001$ & & \\
$R^{2}$ & 0.391 & 0.213 & 0.155 & 0.138 & 0.065 & 0.053 \\
No. of obs. & 30,008 & 30,008 & 30,008 & 30,008 & 30,008 & 30,008 \\
\hline
\end{tabular}




\section{TABLE 5}

\section{Economic Mechanisms: Monitoring}

Table 5 presents the tests on how the monitoring channel explains the effect of foreign institutional ownership on firm innovation. Panel A presents the regressions with firm fixed effects. Foreign institutional ownership is classified into independent and grey foreign institutional ownership (models 1 and 3), or into long-term and short-term foreign institutional ownership (models 2 and 4). All explanatory variables are lagged by 1 year and defined as in Appendix B. Standard errors are clustered at the firm level and reported below in parentheses.

Panel B reports the DID estimates. *, **, and *** indicate significance at the $10 \%, 5 \%$, and $1 \%$ levels, respectively. 
TABLE 5 (continued)

Panel A. Firm Fixed Effects

$\frac{\ln (\text { PATENT })}{\mathrm{X}=\text { INDEPENDENT } \quad \mathrm{X}=\text { LONG_TERM }}$

Variables

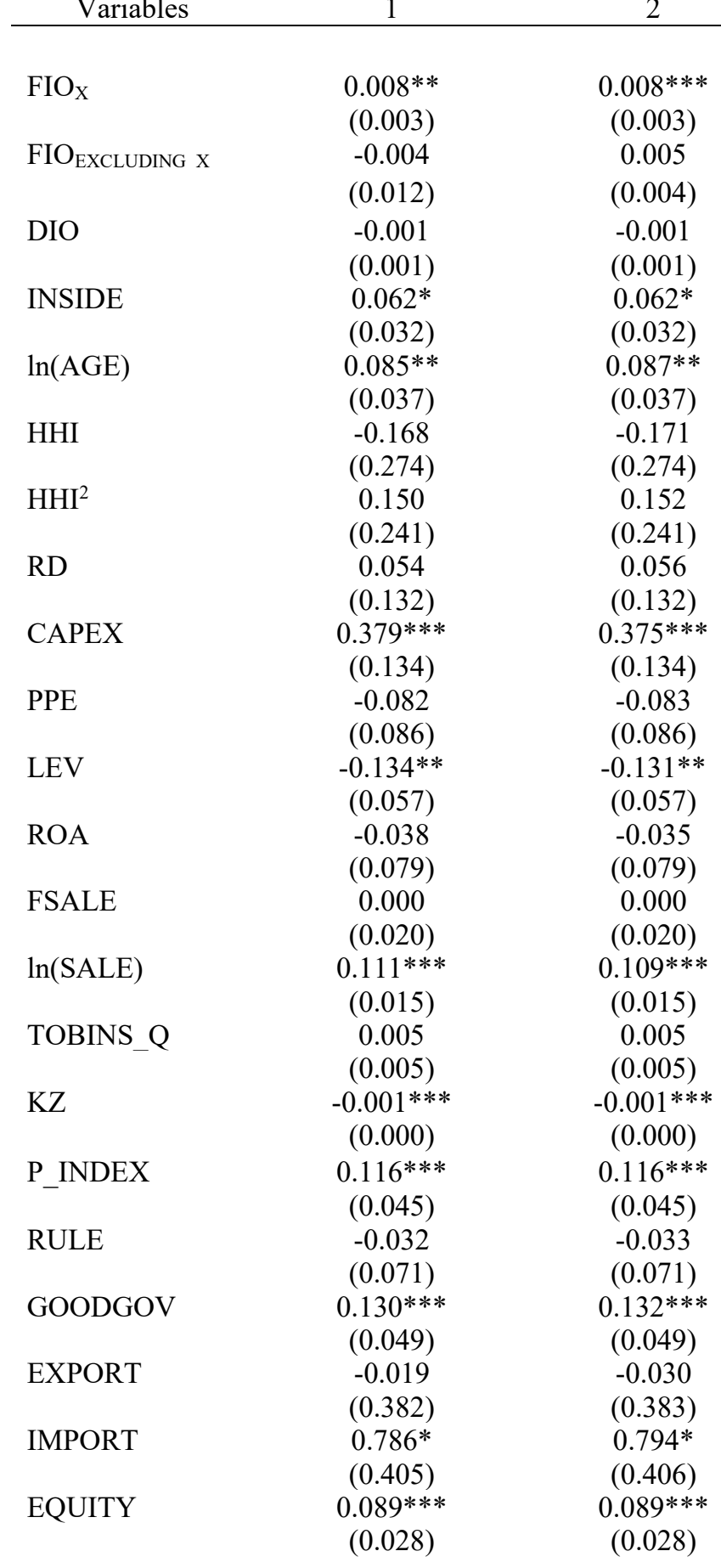

$\ln ($ CITEPAT)

$\mathrm{X}=$ INDEPENDENT $\quad \mathrm{X}=\mathrm{LONG}$-TERM

\begin{tabular}{|c|c|}
\hline 3 & 4 \\
\hline $0.011 * * *$ & $0.011^{* * *}$ \\
\hline$(0.004)$ & $(0.004)$ \\
\hline 0.002 & 0.000 \\
\hline$(0.015)$ & $(0.008)$ \\
\hline-0.000 & -0.001 \\
\hline$(0.002)$ & $(0.002)$ \\
\hline $0.084^{*}$ & $0.084^{*}$ \\
\hline$(0.044)$ & $(0.044)$ \\
\hline $0.117 * *$ & $0.118^{* *}$ \\
\hline$(0.048)$ & $(0.049)$ \\
\hline 0.153 & 0.152 \\
\hline$(0.347)$ & $(0.347)$ \\
\hline 0.048 & 0.049 \\
\hline$(0.290)$ & $(0.290)$ \\
\hline-0.231 & -0.233 \\
\hline$(0.215)$ & $(0.215)$ \\
\hline $0.519^{* * *}$ & $0.519 * * *$ \\
\hline$(0.184)$ & $(0.184)$ \\
\hline-0.095 & -0.096 \\
\hline$(0.114)$ & $(0.114)$ \\
\hline$-0.185 * * *$ & $-0.185^{* * *}$ \\
\hline$(0.070)$ & $(0.071)$ \\
\hline-0.170 & -0.168 \\
\hline (0.109) & (0.109) \\
\hline-0.009 & -0.009 \\
\hline$(0.018)$ & $(0.018)$ \\
\hline $0.115^{* * *}$ & $0.115^{* * *}$ \\
\hline$(0.020)$ & $(0.020)$ \\
\hline 0.001 & 0.001 \\
\hline$(0.008)$ & $(0.008)$ \\
\hline$-0.001 * * *$ & $-0.001 * * *$ \\
\hline$(0.000)$ & $(0.000)$ \\
\hline $0.150 * *$ & $0.150^{* *}$ \\
\hline$(0.062)$ & $(0.062)$ \\
\hline-0.081 & -0.081 \\
\hline$(0.093)$ & $(0.093)$ \\
\hline $0.131 * *$ & $0.131 * *$ \\
\hline$(0.062)$ & $(0.062)$ \\
\hline-0.119 & -0.118 \\
\hline$(0.464)$ & $(0.465)$ \\
\hline 0.485 & 0.482 \\
\hline$(0.517)$ & $(0.517)$ \\
\hline $0.067^{*}$ & $0.067 *$ \\
\hline$(0.036)$ & $(0.036)$ \\
\hline
\end{tabular}




$\begin{array}{lcc}\text { CREDIT } & 0.014 & 0.014 \\ & (0.011) & (0.011) \\ \ln (\mathrm{GDP}) & 0.150^{* *} & 0.152^{* *} \\ & (0.066) & (0.066) \\ \text { Year fixed effects } & \text { Yes } & \text { Yes } \\ \text { Firm fixed effects } & \text { Yes } & \text { Yes } \\ \text { Adj. } R^{2} & 0.872 & 0.872 \\ \text { No. of obs. } & 30,008 & 30,008\end{array}$

$\begin{array}{cc}-0.005 & -0.006 \\ (0.015) & (0.015) \\ 0.103 & 0.104 \\ (0.086) & (0.086) \\ \text { Yes } & \text { Yes } \\ \text { Yes } & \text { Yes } \\ 0.799 & 0.799 \\ 30,008 & 30,008\end{array}$


TABLE 5 (continued)

Panel B. Difference-in-Differences Test

\begin{tabular}{|c|c|c|c|c|}
\hline & $\begin{array}{c}\text { Treatment } \\
\text { Group } \\
\text { After - Before }\end{array}$ & $\begin{array}{c}\text { Control } \\
\text { Group } \\
\text { After - Before }\end{array}$ & $\begin{array}{l}\text { Treatment - Control } \\
\text { DID Estimator }\end{array}$ & $\begin{array}{l}t \text {-Statistics for } \\
\text { DID Estimator }\end{array}$ \\
\hline Variables & 1 & 2 & 3 & 4 \\
\hline \multicolumn{5}{|c|}{ Independent Institutions } \\
\hline $\ln (\mathrm{PATENT})$ & $\begin{array}{c}0.175 \\
(0.039)\end{array}$ & $\begin{array}{c}0.079 \\
(0.035)\end{array}$ & $0.096 * * *$ & 2.567 \\
\hline $\ln ($ CITEPAT $)$ & $\begin{array}{c}0.202 \\
(0.050)\end{array}$ & $\begin{array}{c}0.082 \\
(0.033)\end{array}$ & $0.120 * *$ & 2.165 \\
\hline \multicolumn{5}{|l|}{ Grey Institutions } \\
\hline $\ln (\mathrm{PATENT})$ & $\begin{array}{c}0.160 \\
(0.045)\end{array}$ & $\begin{array}{c}0.079 \\
(0.035)\end{array}$ & 0.081 & 1.610 \\
\hline $\ln ($ CITEPAT $)$ & $\begin{array}{c}0.161 \\
(0.085)\end{array}$ & $\begin{array}{c}0.082 \\
(0.033)\end{array}$ & $0.079 *$ & 1.733 \\
\hline \multicolumn{5}{|c|}{ Long-Term Institutions } \\
\hline $\ln (\mathrm{PATENT})$ & $\begin{array}{c}0.204 \\
(0.044)\end{array}$ & $\begin{array}{c}0.079 \\
(0.035)\end{array}$ & $0.125^{* * *}$ & 3.149 \\
\hline $\ln ($ CITEPAT) & $\begin{array}{c}0.233 \\
(0.041)\end{array}$ & $\begin{array}{c}0.082 \\
(0.033)\end{array}$ & $0.151 * * *$ & 3.246 \\
\hline \multicolumn{5}{|c|}{ Short-Term Institutions } \\
\hline $\ln (\mathrm{PATENT})$ & $\begin{array}{c}0.154 \\
(0.075)\end{array}$ & $\begin{array}{c}0.079 \\
(0.035)\end{array}$ & 0.075 & 1.451 \\
\hline $\ln ($ CITEPAT) & $\begin{array}{c}0.165 \\
(0.084)\end{array}$ & $\begin{array}{c}0.082 \\
(0.033)\end{array}$ & 0.083 & 1.521 \\
\hline
\end{tabular}




\section{TABLE 6}

\section{Economic Mechanisms: Insurance}

Table 6 presents the tests on how the insurance channel explains the effect of foreign institutional ownership on firm innovation. Panel A reports the regression results with firm fixed effects. In model 1, the dependent variable is a dummy variable (CEO_TURN), which equals 1 if the CEO at the end of the fiscal year is different from the CEO at the end of the previous fiscal year, and 0 otherwise. The main independent variable is the interaction between the change in profitability and foreign institutional ownership (FIO $\times \triangle \mathrm{ROA}$ ). Models 2 and 3 show the results of regressions of the change in the managers' compensation on foreign institutional ownership, where the dependent variables are measured by the change in cash and bonus compensation (model 2) and the change in total compensation (model 3). The main independent variable is the interaction between the change in shareholders' wealth and foreign institutional ownership $(\mathrm{FIO} \times \Delta$ WEALTH). Panel B report the DID test results. All explanatory are lagged by 1 year. Variable definitions are in Appendix B. Standard errors clustered at the firm level (Panel A) and bootstrapped and clustered at the firm level (Panel B) are reported below in parentheses. *, **, and $* * *$ indicate significance at the $10 \%, 5 \%$, and $1 \%$ levels, respectively. 
TABLE 6 (continued)

$$
\text { CEO_TURN } \triangle \text { CEO_CASH } \triangle \text { CEO_TOTAL }
$$

Variables

12

3

\section{Panel A. Firm Fixed Effects}

$\mathrm{FIO} \times \triangle \mathrm{ROA}$

$\mathrm{DIO} \times \triangle \mathrm{ROA}$

$0.001 * *$

$(0.000)$

0.000

$(0.000)$

$\triangle \mathrm{ROA}$

$-0.011 * *$

$(0.005)$

FIO $\times \Delta$ WEALTH

$\begin{array}{cc}-0.018^{* *} & -0.027 * * \\ (0.007) & (0.012) \\ 0.002 & 0.003 \\ (0.005) & (0.009) \\ 0.382 * * & 0.458^{* * *}\end{array}$

$\triangle$ WEALTH

$(0.175)$

$(0.176)$

$15.065^{*} \quad 26.776$

FIO

0.000

$(0.006)$

(9.011)

(33.620)

DIO

0.001

$-3.018$

$-24.286$

(0.004)

$\ln (\mathrm{MCAP})$

0.017

(5.688)

(19.870)

$-0.007$

0.047

(0.036)

Year fixed effects

Yes

Firm fixed effects

Yes

Adj. $R^{2}$

0.125

No. of obs.

755

(0.083)

(0.083)

Yes

Yes

0.227

785

Yes

Yes

0.122

785 
TABLE 6 (continued)

\begin{tabular}{|c|c|c|c|}
\hline$\triangle \mathrm{ROA} \times \mathrm{TREAT} \times \mathrm{POST}$ & $\begin{array}{c}0.005 * * * \\
(0.002)\end{array}$ & & \\
\hline$\triangle \mathrm{ROA} \times \mathrm{TREAT}$ & $\begin{array}{c}-0.004 * * \\
(0.002)\end{array}$ & & \\
\hline$\triangle \mathrm{ROA} \times \mathrm{POST}$ & $\begin{array}{c}-0.003 * * * \\
(0.001)\end{array}$ & & \\
\hline$\triangle \mathrm{ROA}$ & $\begin{array}{c}-0.006^{* *} \\
(0.003)\end{array}$ & & \\
\hline$\Delta$ WEALTH $\times$ TREAT $\times$ POST & & $\begin{array}{l}-0.015^{*} \\
(0.008)\end{array}$ & $\begin{array}{c}-0.023 * * * \\
(0.007)\end{array}$ \\
\hline$\triangle$ WEALTH $\times$ TREAT & & $\begin{array}{l}-0.007 \\
(0.010)\end{array}$ & $\begin{array}{l}-0.026 \\
(0.017)\end{array}$ \\
\hline$\Delta \mathrm{WEALTH} \times \mathrm{POST}$ & & $\begin{array}{l}-0.039 \\
(0.085)\end{array}$ & $\begin{array}{c}-0.012 * * \\
(0.006)\end{array}$ \\
\hline$\triangle$ WEALTH & & $\begin{array}{l}0.455^{*} \\
(0.263)\end{array}$ & $\begin{array}{c}0.716^{* * *} \\
(0.226)\end{array}$ \\
\hline TREAT $\times$ POST & $\begin{array}{c}0.028 \\
(0.112)\end{array}$ & $\begin{array}{c}16.786 \\
(13.156)\end{array}$ & $\begin{array}{l}-24.132 \\
(15.643)\end{array}$ \\
\hline $\ln (\mathrm{MCAP})$ & $\begin{array}{l}0.011^{*} \\
(0.006)\end{array}$ & $\begin{array}{c}0.074 \\
(0.042)\end{array}$ & $\begin{array}{l}0.017^{*} \\
(0.009)\end{array}$ \\
\hline Year fixed effects & Yes & Yes & Yes \\
\hline Firm fixed effects & Yes & Yes & Yes \\
\hline Adj. $R^{2}$ & 0.096 & 0.042 & 0.078 \\
\hline No. of obs. & 110 & 121 & 121 \\
\hline
\end{tabular}




\section{TABLE 7}

\section{Economic Mechanisms: Knowledge Spillovers}

Table 7 reports the tests on how the knowledge spillovers channel explains the effect of foreign institutional ownership on firm innovation. A country-level measure of innovativeness is constructed based on 4 ratios: the total number of patents applied by all residents of a country in a year scaled by i) GDP (PATENT_GDP), ii) total population (PATENT_POP), iii) total number of listed firms (PATENT_FIRMS), and iv) country market capitalization (PATENT_MCAP) measured in that year. A country-level measure of governance is based on the anti-self-dealing index of La Porta et al. (2006). An institution's home country is a high- or low-innovation (governance) country if its measure of innovativeness (governance) is above or below the median of all domiciled countries of sample institutional investors. In Panel A, foreign institutional ownership is classified into ownership from high-innovation countries (FIOHIGH_INNO) and ownership from low-innovation countries (FIOLOW_INNO). In Panel B, foreign institutional ownership is classified into ownership from high-innovation and high-governance countries (FIOHIGHINNO_HIGHGOV), high-innovation and low-governance countries (FIOHighinno_Lowgov), low-innovation and high-governance countries (FIOLOwINNO_HIGHGOv), low-innovation and low-governance countries (FIOLOwINNO_LOWGOv). All explanatory variables are lagged by 1 year. Variable definitions are in Appendix B. Standard errors clustered at the firm level are reported below in parentheses. *,**, and *** indicate significance at the $10 \%, 5 \%$, and $1 \%$ levels, respectively. 
TABLE 7 (continued)

$\ln ($ PATENT $)$

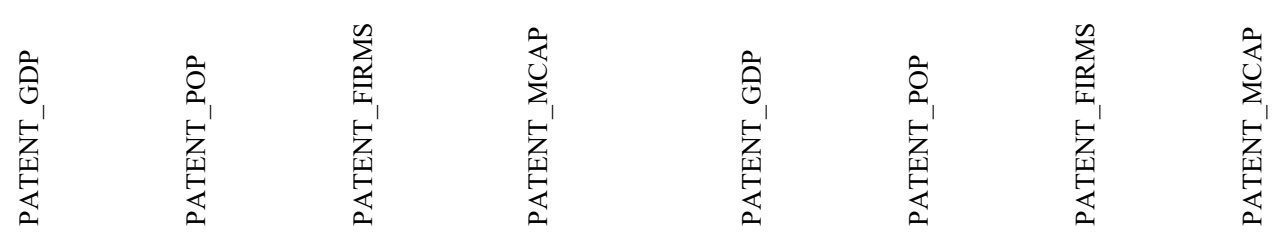

$\ln ($ CITEPAT)

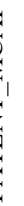

\section{Variables}

1

2

3

4

5

6

7

8

Panel A. Foreign Institutional Ownership Classified By Foreign Institutions' Home-Country Innovativeness

\begin{tabular}{|c|c|c|c|c|c|c|c|c|}
\hline FIOHIGH_INNO & $\begin{array}{l}0.007 * \\
(0.004)\end{array}$ & $\begin{array}{c}0.009^{* * *} \\
(0.003)\end{array}$ & $\begin{array}{l}0.009 * * \\
(0.004)\end{array}$ & $\begin{array}{c}0.011 \\
(0.008)\end{array}$ & $\begin{array}{l}0.011^{* *} \\
(0.005)\end{array}$ & $\begin{array}{c}0.012 * * * \\
(0.004)\end{array}$ & $\begin{array}{c}0.013^{* *} \\
(0.005)\end{array}$ & $\begin{array}{c}0.020^{* *} \\
(0.010)\end{array}$ \\
\hline FIOLOW_INNOV & $\begin{array}{c}0.014 \\
(0.009)\end{array}$ & $\begin{array}{c}0.001 \\
(0.025)\end{array}$ & $\begin{array}{c}0.014 \\
(0.012)\end{array}$ & $\begin{array}{c}0.006 \\
(0.004)\end{array}$ & $\begin{array}{c}0.018 \\
(0.011)\end{array}$ & $\begin{array}{c}0.015 \\
(0.033)\end{array}$ & $\begin{array}{c}0.015 \\
(0.015)\end{array}$ & $\begin{array}{c}0.007 \\
(0.005)\end{array}$ \\
\hline DIO & $\begin{array}{l}-0.001 \\
(0.001)\end{array}$ & $\begin{array}{l}-0.001 \\
(0.001)\end{array}$ & $\begin{array}{l}-0.001 \\
(0.001)\end{array}$ & $\begin{array}{l}-0.001 \\
(0.001)\end{array}$ & $\begin{array}{l}-0.001 \\
(0.002)\end{array}$ & $\begin{array}{l}-0.001 \\
(0.002)\end{array}$ & $\begin{array}{l}-0.001 \\
(0.002)\end{array}$ & $\begin{array}{l}-0.001 \\
(0.002)\end{array}$ \\
\hline INSIDE & $\begin{array}{l}0.062 * \\
(0.032)\end{array}$ & $\begin{array}{l}0.061^{*} \\
(0.032)\end{array}$ & $\begin{array}{l}0.061^{*} \\
(0.032)\end{array}$ & $\begin{array}{l}0.062^{*} \\
(0.032)\end{array}$ & $\begin{array}{l}0.086^{*} \\
(0.044)\end{array}$ & $\begin{array}{l}0.084^{*} \\
(0.044)\end{array}$ & $\begin{array}{l}0.085^{*} \\
(0.044)\end{array}$ & $\begin{array}{l}0.086^{*} \\
(0.044)\end{array}$ \\
\hline $\ln (\mathrm{AGE})$ & $\begin{array}{c}0.087 * * \\
(0.037)\end{array}$ & $\begin{array}{c}0.087 * * \\
(0.038)\end{array}$ & $\begin{array}{c}0.086^{* *} \\
(0.038)\end{array}$ & $\begin{array}{c}0.087 * * \\
(0.038)\end{array}$ & $\begin{array}{l}0.119 * * \\
(0.049)\end{array}$ & $\begin{array}{c}0.118^{* *} \\
(0.049)\end{array}$ & $\begin{array}{c}0.118^{* *} \\
(0.049)\end{array}$ & $\begin{array}{l}0.120^{* *} \\
(0.049)\end{array}$ \\
\hline HHI & $\begin{array}{l}-0.169 \\
(0.274)\end{array}$ & $\begin{array}{l}-0.171 \\
(0.274)\end{array}$ & $\begin{array}{l}-0.169 \\
(0.274)\end{array}$ & $\begin{array}{l}-0.171 \\
(0.274)\end{array}$ & $\begin{array}{c}0.152 \\
(0.346)\end{array}$ & $\begin{array}{c}0.151 \\
(0.347)\end{array}$ & $\begin{array}{c}0.152 \\
(0.347)\end{array}$ & $\begin{array}{c}0.151 \\
(0.347)\end{array}$ \\
\hline $\mathrm{HHI}^{2}$ & $\begin{array}{c}0.149 \\
(0.241)\end{array}$ & $\begin{array}{c}0.151 \\
(0.241)\end{array}$ & $\begin{array}{c}0.150 \\
(0.241)\end{array}$ & $\begin{array}{c}0.151 \\
(0.241)\end{array}$ & $\begin{array}{c}0.046 \\
(0.290)\end{array}$ & $\begin{array}{c}0.049 \\
(0.290)\end{array}$ & $\begin{array}{c}0.048 \\
(0.290)\end{array}$ & $\begin{array}{c}0.048 \\
(0.291)\end{array}$ \\
\hline $\mathrm{RD}$ & $\begin{array}{c}0.053 \\
(0.132)\end{array}$ & $\begin{array}{c}0.055 \\
(0.132)\end{array}$ & $\begin{array}{c}0.055 \\
(0.132)\end{array}$ & $\begin{array}{c}0.054 \\
(0.132)\end{array}$ & $\begin{array}{l}-0.233 \\
(0.215)\end{array}$ & $\begin{array}{l}-0.231 \\
(0.215)\end{array}$ & $\begin{array}{l}-0.230 \\
(0.215)\end{array}$ & $\begin{array}{l}-0.231 \\
(0.215)\end{array}$ \\
\hline CAPEX & $\begin{array}{c}0.378^{* * *} \\
(0.134)\end{array}$ & $\begin{array}{c}0.378^{* * *} \\
(0.134)\end{array}$ & $\begin{array}{c}0.377 * * * \\
(0.134)\end{array}$ & $\begin{array}{c}0.378^{* * *} \\
(0.134)\end{array}$ & $\begin{array}{c}0.517 * * * \\
(0.184)\end{array}$ & $\begin{array}{c}0.519 * * * \\
(0.184)\end{array}$ & $\begin{array}{c}0.518^{* * *} \\
(0.184)\end{array}$ & $\begin{array}{c}0.518^{* * * *} \\
(0.184)\end{array}$ \\
\hline PPE & $\begin{array}{c}-0.080 \\
(0.086)\end{array}$ & $\begin{array}{l}-0.083 \\
(0.086)\end{array}$ & $\begin{array}{l}-0.082 \\
(0.086)\end{array}$ & $\begin{array}{c}-0.081 \\
(0.086)\end{array}$ & $\begin{array}{c}-0.093 \\
(0.114)\end{array}$ & $\begin{array}{l}-0.095 \\
(0.114)\end{array}$ & $\begin{array}{l}-0.095 \\
(0.114)\end{array}$ & $\begin{array}{l}-0.093 \\
(0.114)\end{array}$ \\
\hline LEV & $\begin{array}{c}-0.133^{* *} \\
(0.057)\end{array}$ & $\begin{array}{c}-0.133 * * \\
(0.057)\end{array}$ & $\begin{array}{c}-0.132 * * \\
(0.057)\end{array}$ & $\begin{array}{c}-0.134 * * \\
(0.058)\end{array}$ & $\begin{array}{c}-0.184 * * * \\
(0.071)\end{array}$ & $\begin{array}{c}-0.185^{* * *} \\
(0.071)\end{array}$ & $\begin{array}{c}-0.185^{* * *} \\
(0.071)\end{array}$ & $\begin{array}{c}-0.185^{* * *} \\
(0.071)\end{array}$ \\
\hline ROA & $\begin{array}{c}-0.039 \\
(0.079)\end{array}$ & $\begin{array}{l}-0.037 \\
(0.079)\end{array}$ & $\begin{array}{l}-0.039 \\
(0.079)\end{array}$ & $\begin{array}{c}-0.040 \\
(0.079)\end{array}$ & $\begin{array}{l}-0.170 \\
(0.108)\end{array}$ & $\begin{array}{l}-0.170 \\
(0.108)\end{array}$ & $\begin{array}{l}-0.170 \\
(0.108)\end{array}$ & $\begin{array}{l}-0.171 \\
(0.108)\end{array}$ \\
\hline FSALE & $\begin{array}{c}0.001 \\
(0.019)\end{array}$ & $\begin{array}{c}0.000 \\
(0.020)\end{array}$ & $\begin{array}{c}0.001 \\
(0.020)\end{array}$ & $\begin{array}{c}0.000 \\
(0.020)\end{array}$ & $\begin{array}{c}-0.009 \\
(0.018)\end{array}$ & $\begin{array}{l}-0.009 \\
(0.018)\end{array}$ & $\begin{array}{c}-0.009 \\
(0.018)\end{array}$ & $\begin{array}{c}-0.009 \\
(0.018)\end{array}$ \\
\hline $\ln (\mathrm{SALE})$ & $\begin{array}{c}0.110^{* * *} \\
(0.015)\end{array}$ & $\begin{array}{c}0.110^{* * *} \\
(0.015)\end{array}$ & $\begin{array}{c}0.110^{* * *} \\
(0.015)\end{array}$ & $\begin{array}{c}0.110^{* * *} \\
(0.015)\end{array}$ & $\begin{array}{c}0.114 * * * \\
(0.020)\end{array}$ & $\begin{array}{c}0.115^{* * *} \\
(0.020)\end{array}$ & $\begin{array}{c}0.114 * * * \\
(0.020)\end{array}$ & $\begin{array}{c}0.115^{* * *} \\
(0.020)\end{array}$ \\
\hline TOBINS_Q & $\begin{array}{c}0.005 \\
(0.005)\end{array}$ & $\begin{array}{c}0.005 \\
(0.005)\end{array}$ & $\begin{array}{c}0.005 \\
(0.005)\end{array}$ & $\begin{array}{c}0.005 \\
(0.005)\end{array}$ & $\begin{array}{c}0.001 \\
(0.008)\end{array}$ & $\begin{array}{c}0.001 \\
(0.008)\end{array}$ & $\begin{array}{c}0.001 \\
(0.008)\end{array}$ & $\begin{array}{c}0.001 \\
(0.008)\end{array}$ \\
\hline KZ & $\begin{array}{c}-0.001 * * * \\
(0.000)\end{array}$ & $\begin{array}{c}-0.001 * * * \\
(0.000)\end{array}$ & $\begin{array}{c}-0.001 * * * \\
(0.000)\end{array}$ & $\begin{array}{c}-0.001 * * * \\
(0.000)\end{array}$ & $\begin{array}{c}-0.001 * * * \\
(0.000)\end{array}$ & $\begin{array}{c}-0.001 * * * \\
(0.000)\end{array}$ & $\begin{array}{c}-0.001 * * * \\
(0.000)\end{array}$ & $\begin{array}{c}-0.001 * * * \\
(0.000)\end{array}$ \\
\hline P_INDEX & $\begin{array}{l}0.114 * * \\
(0.044)\end{array}$ & $\begin{array}{c}0.117 * * * \\
(0.044)\end{array}$ & $\begin{array}{c}0.115 * * * \\
(0.044)\end{array}$ & $\begin{array}{c}0.115^{* * *} \\
(0.044)\end{array}$ & $\begin{array}{c}0.148^{* *} \\
(0.062)\end{array}$ & $\begin{array}{c}0.151^{* *} \\
(0.061)\end{array}$ & $\begin{array}{c}0.150^{* *} \\
(0.061)\end{array}$ & $\begin{array}{c}0.150^{* *} \\
(0.062)\end{array}$ \\
\hline
\end{tabular}




$\begin{array}{lcccccccc}\text { RULE } & -0.033 & -0.031 & -0.031 & -0.033 & -0.081 & -0.080 & -0.078 & -0.081 \\ & (0.071) & (0.071) & (0.071) & (0.071) & (0.093) & (0.093) & (0.093) & (0.093) \\ \text { GOODGOV } & 0.134^{* * *} & 0.130^{* * *} & 0.131^{* * *} & 0.133^{* * *} & 0.133^{* *} & 0.130^{* *} & 0.129^{* *} & 0.131^{* *} \\ & (0.049) & (0.049) & (0.049) & (0.049) & (0.062) & (0.062) & (0.062) & (0.062) \\ \text { EXPORT } & -0.043 & -0.029 & -0.042 & -0.039 & -0.142 & -0.123 & -0.137 & -0.136 \\ & (0.383) & (0.383) & (0.384) & (0.383) & (0.464) & (0.465) & (0.465) & (0.465) \\ \text { IMPORT } & 0.803^{* *} & 0.792^{*} & 0.803^{* *} & 0.802^{* *} & 0.501 & 0.486 & 0.497 & 0.500 \\ & (0.406) & (0.406) & (0.406) & (0.406) & (0.517) & (0.517) & (0.518) & (0.518) \\ \text { EQUITY } & 0.091^{* * *} & 0.089^{* * *} & 0.090^{* * *} & 0.090^{* * *} & 0.069^{*} & 0.067^{*} & 0.068^{*} & 0.068^{*} \\ & (0.028) & (0.028) & (0.028) & (0.028) & (0.036) & (0.036) & (0.036) & (0.036) \\ \text { CREDIT } & 0.014 & 0.014 & 0.014 & 0.014 & -0.005 & -0.006 & -0.005 & -0.005 \\ & (0.011) & (0.011) & (0.011) & (0.011) & (0.015) & (0.015) & (0.015) & (0.015) \\ \text { ln(GDP) } & 0.149^{* *} & 0.152^{* *} & 0.150^{* *} & 0.150^{* *} & 0.102 & 0.104 & 0.104 & 0.105 \\ & (0.066) & (0.066) & (0.066) & (0.066) & (0.086) & (0.086) & (0.086) & (0.086) \\ \text { Year fixed effects } & \text { Yes } & \text { Yes } & \text { Yes } & \text { Yes } & \text { Yes } & \text { Yes } & \text { Yes } & \text { Yes } \\ \text { Firm fixed effects } & \text { Yes } & \text { Yes } & \text { Yes } & \text { Yes } & \text { Yes } & \text { Yes } & \text { Yes } & \text { Yes } \\ \text { Adj. } R^{2} & 0.872 & 0.872 & 0.872 & 0.872 & 0.799 & 0.799 & 0.799 & 0.799 \\ \text { No. of obs. } & 30,008 & 30,008 & 30,008 & 30,008 & 30,008 & 30,008 & 30,008 & 30,008\end{array}$


TABLE 7 (continued)

Panel B. Foreign Institutional Ownership Classified By Foreign Institutions' Home-Country Innovativeness and Governance

\begin{tabular}{lcccccccc} 
FIO $_{\text {HIGHINNO_HIGHGOV }}$ & $0.009^{* * *}$ & $0.007^{*}$ & $0.010^{* *}$ & $0.013^{*}$ & $0.011^{* *}$ & $0.009^{*}$ & $0.012^{* *}$ & $0.018^{*}$ \\
& $(0.003)$ & $(0.004)$ & $(0.005)$ & $(0.008)$ & $(0.005)$ & $(0.006)$ & $(0.006)$ & $(0.010)$ \\
FIOHIGHINNO_LOWGOV & $0.004^{* *}$ & $0.003^{*}$ & $0.005^{* * *}$ & 0.004 & $0.004^{* *}$ & $0.004^{* *}$ & $0.005^{* * *}$ & 0.003 \\
& $(0.002)$ & $(0.002)$ & $(0.002)$ & $(0.003)$ & $(0.002)$ & $(0.002)$ & $(0.002)$ & $(0.003)$ \\
FIO $_{\text {LOWINNO_HIGHGOV }}$ & 0.013 & 0.019 & $0.011^{*}$ & $0.005^{*}$ & 0.019 & 0.035 & $0.011^{* *}$ & $0.005^{*}$ \\
& $(0.009)$ & $(0.012)$ & $(0.006)$ & $(0.003)$ & $(0.012)$ & $(0.025)$ & $(0.005)$ & $(0.003)$ \\
FIO & 0.009 & 0.008 & 0.005 & 0.001 & 0.008 & 0.006 & 0.004 & 0.006 \\
& $(0.006)$ & $(0.012)$ & $(0.009)$ & $(0.004)$ & $(0.008)$ & $(0.015)$ & $(0.011)$ & $(0.005)$ \\
Other controls & Yes & Yes & Yes & Yes & Yes & Yes & Yes & Yes \\
Year fixed effects & Yes & Yes & Yes & Yes & Yes & Yes & Yes & Yes \\
Firm fixed effects & Yes & Yes & Yes & Yes & Yes & Yes & Yes & Yes \\
Adj. $R^{2}$ & 0.872 & 0.872 & 0.872 & 0.872 & 0.799 & 0.799 & 0.799 & 0.799 \\
No. of obs. & 30,008 & 30,008 & 30,008 & 30,008 & 30,008 & 30,008 & 30,008 & 30,008 \\
\hline
\end{tabular}




\section{FIGURE 1}

\section{Innovation Output of Treatment and Control Firms Surrounding the Passage of the}

\section{JGTRRA in 2003}

Figure 1 shows the average innovation output of the treatment and control firms from 3 years before to 3 years after the passage of the JGTRRA in 2003. The event year is denoted as year 0 (2003). The sample contains 456 unique treatment firms and 228 unique control firms. Graph A reports the mean logarithm of the total number of patents $(\ln (\mathrm{PATENT}))$ and Graph B reports the mean natural logarithm of the total number of citations per patent $(\ln ($ CITEPAT $))$.

\section{Graph A. $\ln (\mathrm{PATENT})$}

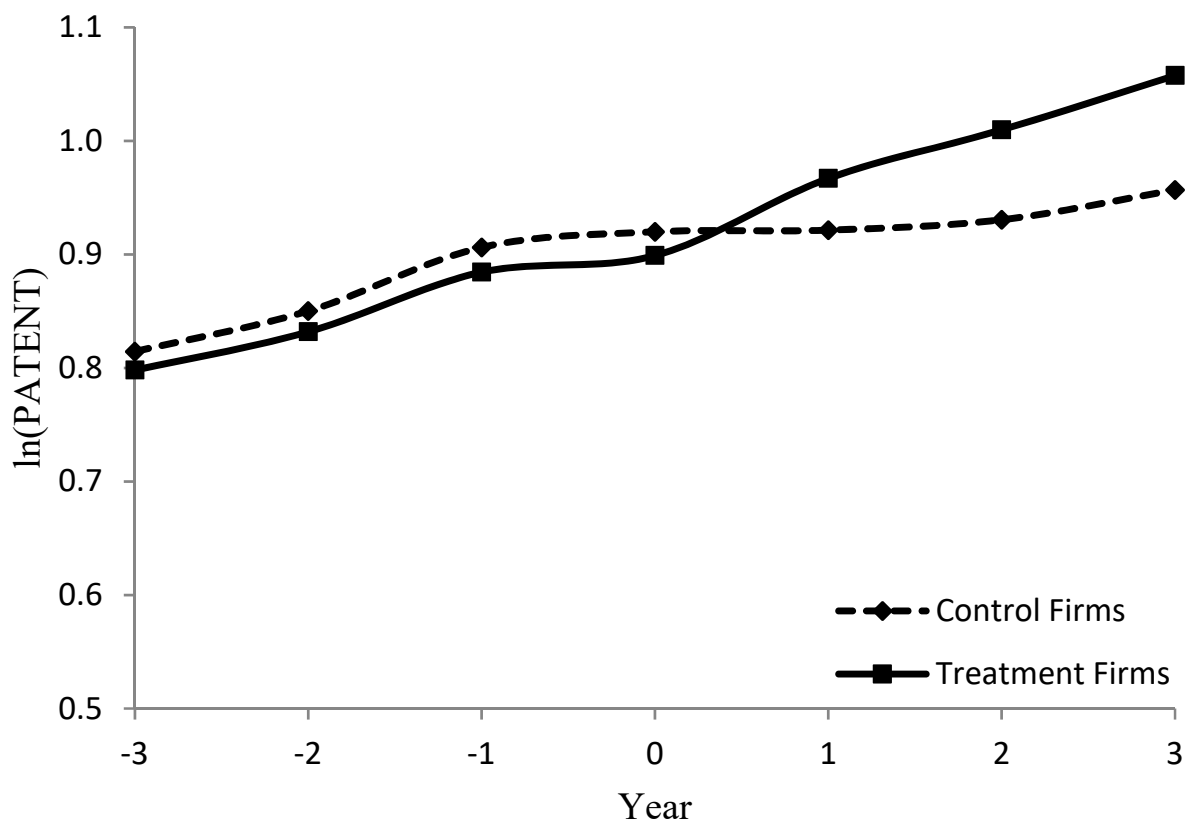


FIGURE 1 (continued)

Graph B. $\ln ($ CITEPAT)

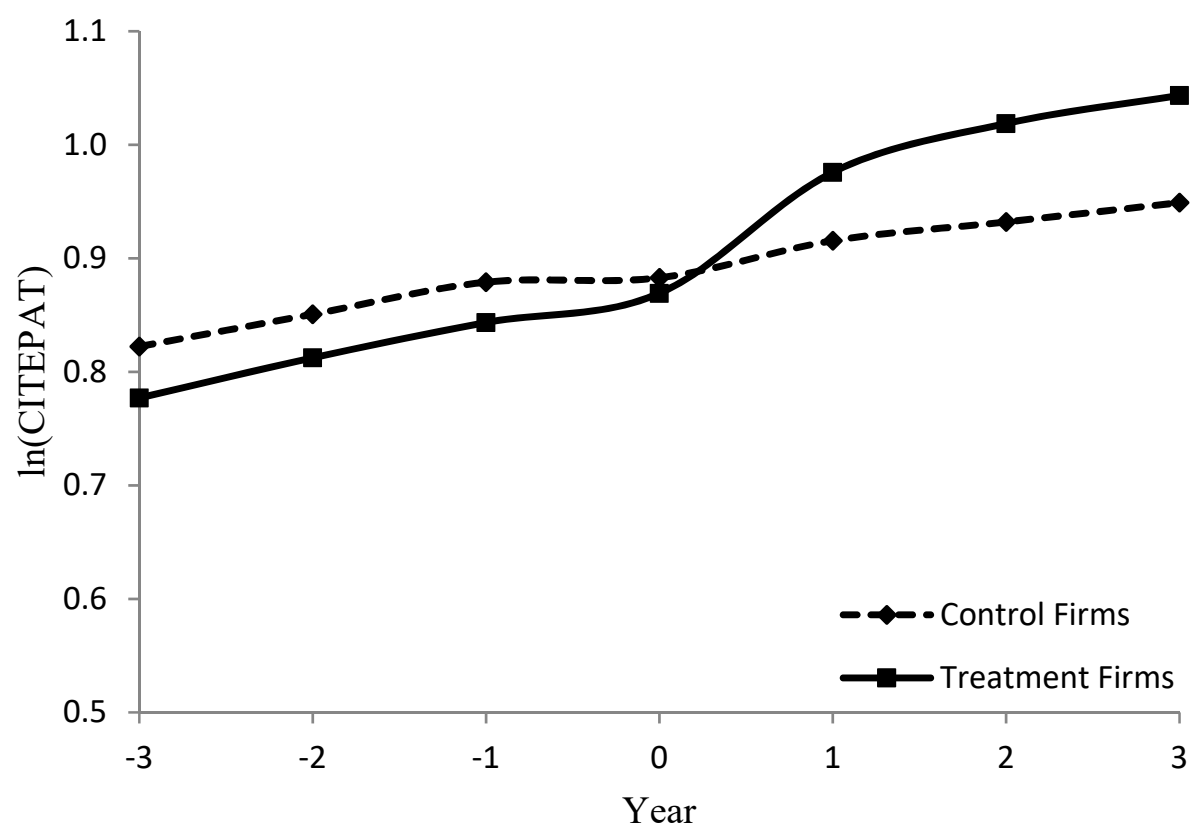

